\title{
Analysis of Shading Effects in Solar PV System
}

\author{
Dushengere Bernadette ${ }^{1,2}$, Maurice Twizerimana ${ }^{1,3,4, *}$, Alexis Bakundukize ${ }^{1}$, \\ Bizabakoraho Jean Pierre ${ }^{1}$, Nsekambabaye Theoneste ${ }^{1}$ \\ ${ }^{1}$ African Centre of Excellence in Energy for Sustainable Development (ACE-ESD), College of Science and Technology, University of Rwanda, \\ Kigali, Rwanda \\ ${ }^{2}$ Department of Mechanical and Production Engineering, School of Engineering, Moi University, Eldoret, Kenya \\ ${ }^{3}$ Department of Manufacturing, Industrial and Textile Engineering, School of Engineering, Moi University, Eldoret, Kenya \\ ${ }^{4}$ Africa Centre of Excellence II in Phytochemicals, Textiles and Renewable Energy (ACE II PTRE), Moi University, Eldoret, Kenya
}

\section{Email address:}

twizerimanamaurice@gmail.com (M. Twizerimana), bdushengere@gmail.com (D. Bernadette), utayaalex482@gmail.com (A. Bakundukize), Jbizaba@gmail (J. P. Bizabakoraho),nsekambabayet@gmail.com (T. Nsekambabaye)

${ }^{*}$ Corresponding author

\section{To cite this article:}

Dushengere Bernadette, Maurice Twizerimana, Alexis Bakundukize, Bizabakoraho Jean Pierre, Nsekambabaye Theoneste. Analysis of Shading Effects in Solar PV System. International Journal of Sustainable and Green Energy. Vol. 10, No. 2, 2021, pp. 47-62.

doi: $10.11648 /$ j.ijrse. 20211002.13

Received: April 10, 2021; Accepted: April 26, 2021; Published: May 8, 2021

\begin{abstract}
Due to its advantages, the use of clean energy in general and especially solar PV systems offer a great solution to problems that people face in their everyday life. Generation of energy using solar PV system technology is cheaper and clean technology compared to one of the fossil fuels. Aside from its advantages, this technology still has some drawbacks that affect its performance where the ones caused by shadows are considered as one of the big problems. This research work showed laboratory experiments and simulations to see how the system is affected by shading where a $1.5 \mathrm{kWp} \mathrm{PV}$ system has been used for the study. The system has been simulated with PVsyst (7.0.6 version) and experimented within the University of Rwanda/ African Center of Excellence in Energy Studies for Sustainable Development (UR/ACE-ESD) High E-Tech Smart Grid Laboratory. Laboratory experiments showed that whatever shade is applied to the system, the DC voltage and current change (increases or decrease) and DC power decreases. In the simulation, it has been notified that the irradiance losses are dependent on the time of a day, sun position, and the rate of created shadow. From the simulated results, annual energy produced and near shading losses in the non-shaded system is $2373 \mathrm{kWh}$ and $0 \%$ respectively while in the shaded system, the annual energy produced was $2055 \mathrm{kWh}$ and $2.1 \%$ of near shading losses. This undoubtedly disturbs the performance of the power system as well as other related works. Based on the result for this work, shadow affects the performance of PV systems and the rate at which the PV system is affected depends on the shaded area, position, and how much radiation reaches that shaded area. This increases the system's instability as it can lose its ability to generate power at the maximum due to the user control algorithm as well as degradation of the output that a PV panel can produce. Furthermore, investigations need to be carried out to modify this work. Providers of energy based on solar systems should sensitize shading issues towards their beneficiaries, and make a follow-up to installed systems so that users can give special attention to shading issues while they operate their system. It is recommended to continue this research within Rwandan Solar power plants considered as a case study for more investigation.
\end{abstract}

Keywords: PV Systems, Shading Effect, Performance of PV Module, PVSYST Simulation

\section{Introduction}

In solar photovoltaic (SPV) systems, the irradiation of the sun at high frequency is captured by an array of semiconductors photovoltaic (PV) cells which convert that solar radiation directly into direct current electricity where it can be used directly or stored for later use [1]. In the world, one of the quickest growing enterprises is PV and it has changed significantly in the course of the most previous couple of years. The competitiveness of this field is increasing, in 2013 for the first time in more than a decade, solar was over all other renewable energy technologies in the 
sense of new generating capacity installed with an increase of 29 percent compared with 2012 [2]. Worldwide total PV installations represented 1.8 gigawatts $(\mathrm{GW})$ in 2000 and $71.1 \mathrm{GW}$ in 2011 with a growth rate of $44 \%$ [3]. The rate of increase in production based on PV in the past 15 years has been shown with a yearly rate growth of over $40 \%$ [4]. By the end of 2018, global cumulative installed PV reached 480
GW of which about $180 \mathrm{GW}$ were utility scaled plants and the reports forecasted that solar PV will reach a cumulative capacity of $2840 \mathrm{GW}$ globally by 2030 [5]. Taking a look at Figure 1 illustrates the improvement in the PV industry as the years go on. This development led many researchers to emphasize many problems related to this industry and they argued the significant impact of shading on PV systems.

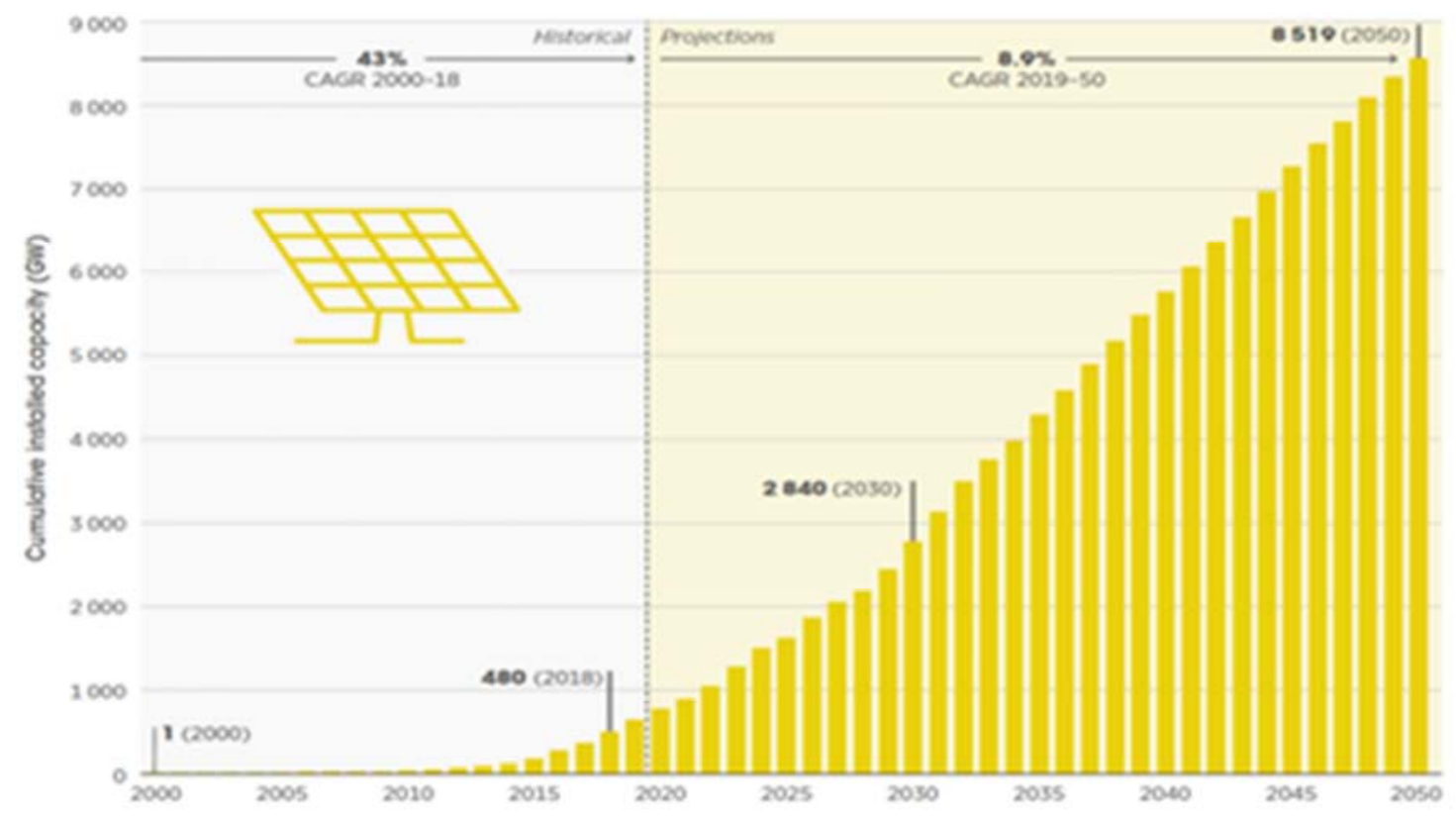

Figure 1. Historical and projections cumulative solar PV capacity [6].

As energy demand is increasing all over the world, many energy resources are needed to meet the demand and looking among those resources which are not harmful to the users as well as the environment. Many developing countries are suffering due to the use of conventional energy resources, it is why governments and other institutions are promoting the use of energy based on renewable resources. Electrical energy has a great impact on the economic development of every country around the globe as it plays a vital role in performing many activities in our communities. The need for electricity is increasing as the population all over the world is increasing. This population's growth leads to an increase in energy demand and more energy resources are needed to meet that demand. Apart from being depleted, the utilization of conventional energy resources is not environmentally friendly thus affect human beings, the use of renewable energy resources will contribute to meet the demand as it does not affect the environment.

Among renewable energy technologies, solar energy is an alternative and green energy which can be used as a solution to those problems facing by the world. Availability of the sun in numerous places around the globe makes the usage of solar energy based on photovoltaic to be more feasible compared to other renewable energy technologies [7]. Even if the importance of solar energy has been seen, there are still some effects that compromise its use due to different situations where some of them are inevitable. As it has been discussed by many authors [8-10] the PV system can be used as a standalone or utility-interactive system [7], whether used as standalone or utility connected, shading affects the energy production of the system. Apart from a reduction in the output power in the PV system that can be caused by shade, also shade causes thermal stress on the module. When a PV cell is shaded, the insolation is reduced by shading and result in a reduction of photocurrent. Because of the series connection of all the cells, the current for all the cells is reduced and according to the level of shading then the thermal stress causes the degradation in the area affected by high temperature [11]. Therefore, analysis of the shading effect will positively affect the development of PV-related projects in the future by taking into consideration how to deal with those effects.

At the same time, solar power generation still counts some problems like low solar PV conversion efficiency [12] and since output power of a PV module depends on many things including solar irradiance, wind speed, cell temperature, geographical location, module orientation, weather conditions, etc., it strongly compromised by reduction of solar radiation intensity $[7,13]$. Disregarding such mentioned problems, the shading effect is a very crucial problem in the PV system industry. Some conditions of shading in this field are preventable whereas others are not, including those ones caused by weather conditions. Those shades cause the PV module to receive less intensity of sunlight and they vary from one factor to another like environmental conditions which not constant during the year, climate change, or even 
shadows from neighboring objects [14]. Figure 2. shows some shading conditions due to different causes.

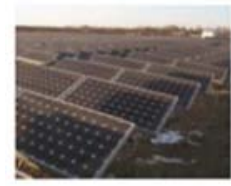

a

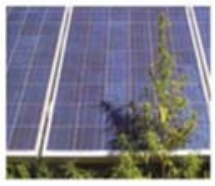

b

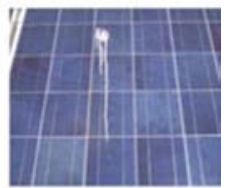

c
Figure 2. Different shading condition (a) nearby module shading in a tracking PV system, (b) plant shading, and (c) bird dropping shading.

Like many places in the world, renewable energy utilization and SPV system particularly are fastly growing in Rwanda. Therefore, people need to have enough knowledge to positively affect its use as well as the development of future related projects while taking into consideration the related problems. Regarding related literature, shading effects have been discussed by different researchers $[10,11,15,16]$. Such studies were done throughout the world, unfortunately, many Rwandans have not yet effectively informed so that they can deal with those conditions. This research work will contribute in terms of helping Rwandans to be aware of the effects of shading on their systems. Being informed on this will help them to avoid those effects where applicable and apply the technical mitigations techniques for those which are inevitable. The objective of this research was to analyze the shading effects in a PV system. The simulation of both non shaded and shaded PV systems and see their results, the comparison of the two systems in terms of performances, and the performance analysis for both systems in terms of efficiency, durability, and performance have been discussed in this paper.

\section{PV System Overview}

\subsection{Description of a PV System}

PV systems convert sunlight energy into electrical energy using power electronic devices. SPV is becoming more useful in our daily lives because it is being deployed in many basic needs devices such as calculators, wristwatches, water pumping systems, transport systems, and street lighting systems, etc. Also, there are small and large solar power plants generating electricity. Depending on the type of the system, location, and applications where they are used, a typical PV system contains more than one of the following devices: PV module, battery, power conditioning device, load, and balance of the system. PV cells are combined to build up PV modules which can also be connected to build up PV panels or PV arrays, to produce electrical power reliably and conveniently for any electrical demand requirement, no matter how large or small it is [8]. Those components are for a standalone (simple SPV system). Figure 3 shows the schematic diagram of a Photovoltaic System with a storage unit. For other systems like a hybrid, grid-connected systems, additional elements like transformer, protective equipment, metering equipment power conditioner unit are required.

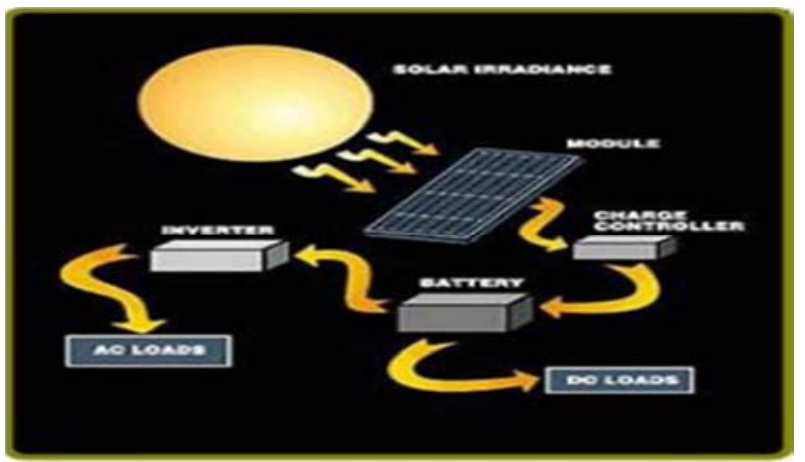

Figure 3. Schematic diagram of Photovoltaic System with storage unit [1].

According to the system's purpose and configuration, PV Systems are classified into two main types which are standalone and utility-connected systems. Their others like hybrid systems, an independent system which does not require an inverter for $\mathrm{DC}$ to $\mathrm{AC}$ conversion and other systems without storage system and is considered in standalone SPV system [17]. Those systems types are designed to power AC and/or DC loads. Figure 4. illustrates the main types and components of the PV system.

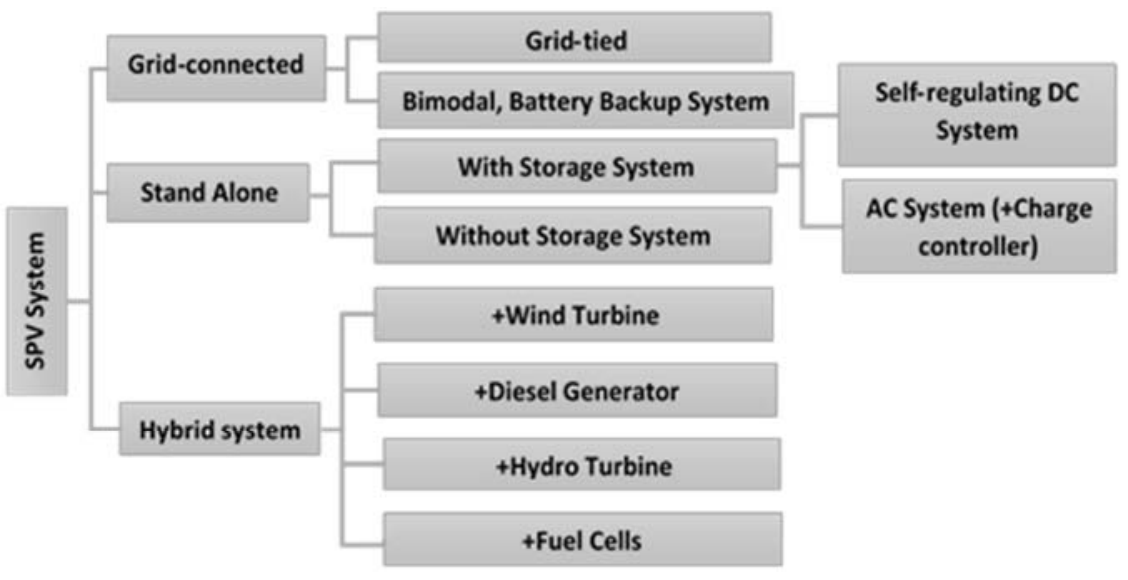

Figure 4. PV system classification [18]. 


\subsection{A PV Cell Model Characteristic}

A PV cell is a main and fundamental unit in a solar PV system that serves the role of converting directly the solar radiation into electricity (DC). A module is made by a combination of more PV cells. Many PV modules are connected either in series or/and in parallel to form an array and its number and connections depend on the required output power [7]. Figure 5 represents a PV cell. The three parallel parameters, source current Iph, diode D, and shunt resistance Rsh are connected to the series resistance Rs and the amount of flowing current depends on solar radiation that strike the cell as well as the present temperature in the location [10].

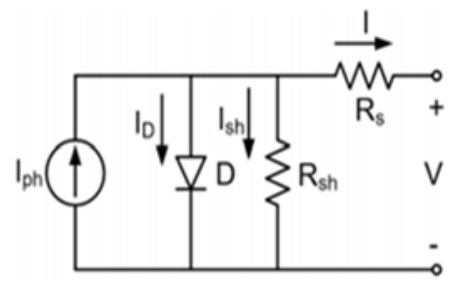

Figure 5. Equivalent circuit of $P V$ cell.

The circuit model formed by one diode and two resistors is defined by the following equation

$$
\begin{gathered}
I=I_{P V}-I_{O}\left[\exp \left(\frac{V+I R_{S}}{\alpha V_{T}}\right)-1\right]-\frac{V+I R s}{R s h} \\
V_{T}=n \frac{K T}{q}
\end{gathered}
$$

Where,

$I_{P V}$ : the photocurrent delivered by the constant current source;

$I_{O}$ : The reverse saturation current corresponding to the diode;

$R_{S}$ : series resistor that takes into account losses in cell solder bonds, interconnection, etc

$R_{S h}$ : shunt resistor that takes into account the current leakage through the high conductivity shunts across the $p-n$ junction;

$\alpha$ : Ideality factor,

$\mathrm{n}$ : the number of cells in series,

T: The cell temperature in Kelvin,

$V_{T}$ : Thermal voltage of the diode and depends on the charge of the electron,

$\mathrm{q}$ : is a charge of an electron $\left(1.6 \times 10^{19} \mathrm{C}\right)$,

$\mathrm{k}$ : The Boltzmann's constant $\left(1.38 \times 10^{23} \mathrm{j} / \mathrm{K}\right)$

\subsection{Types of PV Modules Technology}

They are types of SPV modules. Silicon is the main material used in making PV cells/modules. Figure 6 shows various PV cells manufactured from silicon materials.

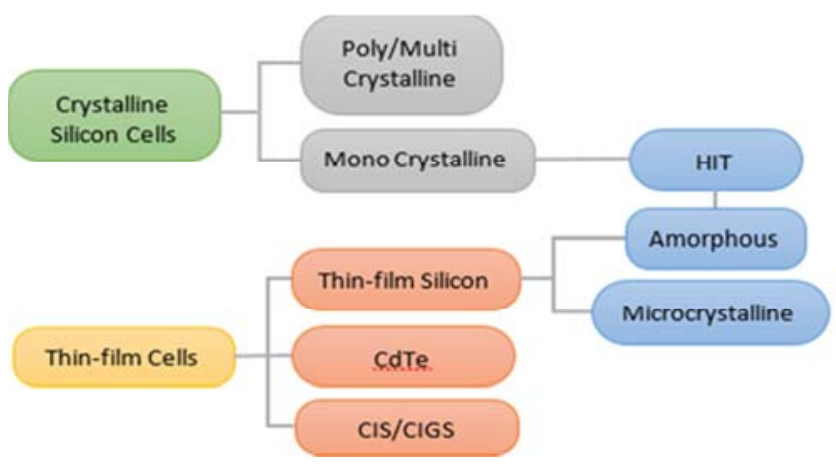

Figure 6. PV technology classes [19].

The main important positivity and negativities factors are of key advantages and disadvantages, potential issues of each stated PV technology are summarized in Table $1[18,20]$.

\subsection{Maximum PowerPoint and PV Array Tilt}

When a PV panel receives uniform irradiation during the normal condition, its I-V characteristics show a single maximum power point where it can produce the maximum power. Devices called maximum power point trackers (MPPT) are used so that arrays keep their ability to generate power at the maximum and there are numerous control algorithms through them that MPPT can be applied and the common algorithm is known as perturbation and observation (P\&O) [21]. The condition for an array to deliver the maximum power is when the angle between the sun's radiation and the receiving surface is a right angle. To reach this condition, the modules' mounting structure can travel behind the sun's motion, trackers were designed to adjust for azimuth and elevation [22].

\begin{tabular}{|c|c|c|}
\hline PV Technology & Strengths & Weaknesses \\
\hline Crystalline Silicon & $\begin{array}{l}\text { For (Mono-Si) } \\
\text { efficiency: } 15-20 \%(21.5 \% \text { most extreme current }) \\
\text { lastingness up to } 25 \text { years } \\
\text { space-efficient }\end{array}$ & $\begin{array}{l}\text { expensive } \\
\text { sensibility to ambient temperature } \\
\text { sensibility to shading issues, snow, and dirt } \\
\text { wasteful manufacturing process }\end{array}$ \\
\hline Crystalline Silicon & $\begin{array}{l}\text { For }(\mathrm{p}-\mathrm{Si}) \\
\text { nor complex, cost-productive, and not an inefficient manufacturing process } \\
\text { insignificant intolerance to the high surrounding temperature }\end{array}$ & $\begin{array}{l}\text { expensive } \\
\text { sensibility to ambient temperature } \\
\text { sensibility to shading issues, snow, and dirt } \\
\text { wasteful manufacturing process }\end{array}$ \\
\hline Thin-film (TFSC) & $\begin{array}{l}\text { cost-productive and simple manufacturing process } \\
\text { flexible configurations applicable to different installations } \\
\text { high resistance to shading issues and ambient temperature variation }\end{array}$ & $\begin{array}{l}\text { low productivity: } 9-12 \% \\
\text { low space efficiency } \\
\text { high degradation }\end{array}$ \\
\hline
\end{tabular}

Table 1. Difference between PV cell technologies 


\subsection{Output Characteristic of a PV cell}

One of the crucial characteristics of the SPV system is the $\mathrm{I}-\mathrm{V}$ and curves of a photovoltaic cell, module, or array. I-V and $\mathrm{P}-\mathrm{V}$ curves of a PV cell with their main parameters are represented in Figure 7. This curve shows how a PV cell or module can generate energy according to the module's inputs like solar irradiation, cell temperature, the orientation of the module [23]. This curve also draws the possibilities of a couple of voltage and current at which the module can operate for the condition of the constant input. Mostly those parameters illustrated on the curve come out on the module's nameplate so that the users consider them before its installation as well as use.

Isc represents the cell current when it is shorted means its maximum corresponds to zero voltage and the circuit impedance is low.

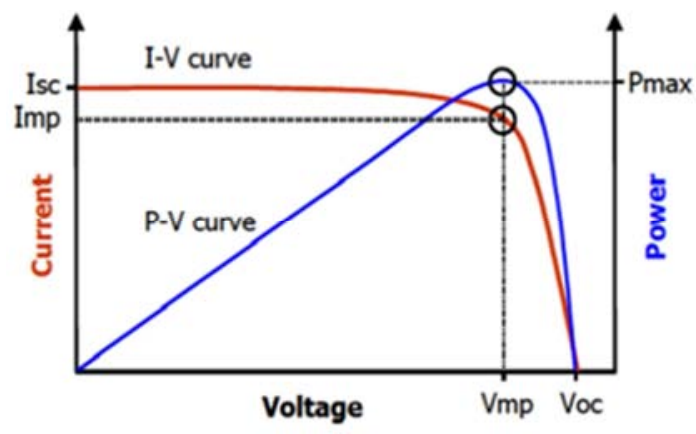

Figure 7. I-V and PV characteristics of PV cell [24].

$$
I_{S C}=I_{P V}-I_{O}\left[\exp \left(\frac{I_{S C} R_{S}}{\alpha V_{T}}\right)-1\right]-\frac{I_{S C} R_{S}}{R_{S h}}
$$

$\mathrm{V}_{\mathrm{oc}}$ (open circuit voltage) is the voltage across the cell when the circuit is open, its maximum corresponds to zero current.

$$
O=I_{P V}-I_{O}\left[\exp \left(\frac{V_{O C}}{\propto V_{T}}\right)-1\right]-\frac{V_{O C}}{R_{S h}}
$$

The point $\left(\mathrm{I}_{\mathrm{mp}}, \mathrm{V}_{\mathrm{mp}}\right)$ on the I-V curve is the maximum point at which the maximum DC power can be generated by the module/array.

$$
I_{m p}=I_{P V}-I_{O}\left[\exp \left(\frac{V_{m p}+I_{m p} R_{S}}{\propto V_{T}}\right)-1\right]-\left(\frac{V_{m p}+I_{m p} R_{S}}{R_{S h}}\right)
$$

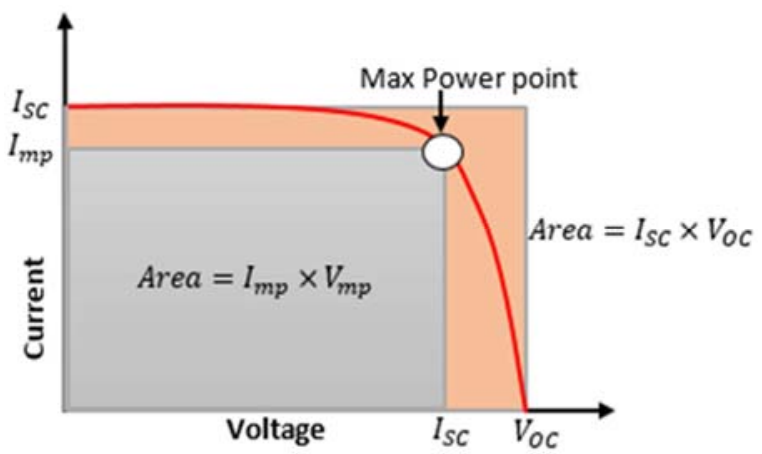

Figure 8. The Fill Factor, defined as the gray area divided by the cross-hatched area [24].
DC output power to be produced in the system strongly depends on irradiance intensity, the more it increases the more output power generated, in the other hand the module's temperature is inversely proportional to the output power [25]. Another important parameter is the fill factor (FF) that helps to measure the cell capability by showing both maximum powers practically and ideally and its calculation is shown in equation 6 .

$$
F F=\frac{I_{m p} \times V_{m p}}{I_{S C} \times V_{O C}}
$$

Where, Imp: Maximum power current Isc: Short circuit current Vmp: Maximum power voltage Voc: Open circuit voltage

The real fill factor magnitude strongly depends on the manufacturer as well as module technology. Additionally, any factor which decreases the fill factor will in turn decreases the output power by reducing its maximum power point, Figure 9 represents some factors that reduce where among them different losses have been shown on the I-V curve [24].

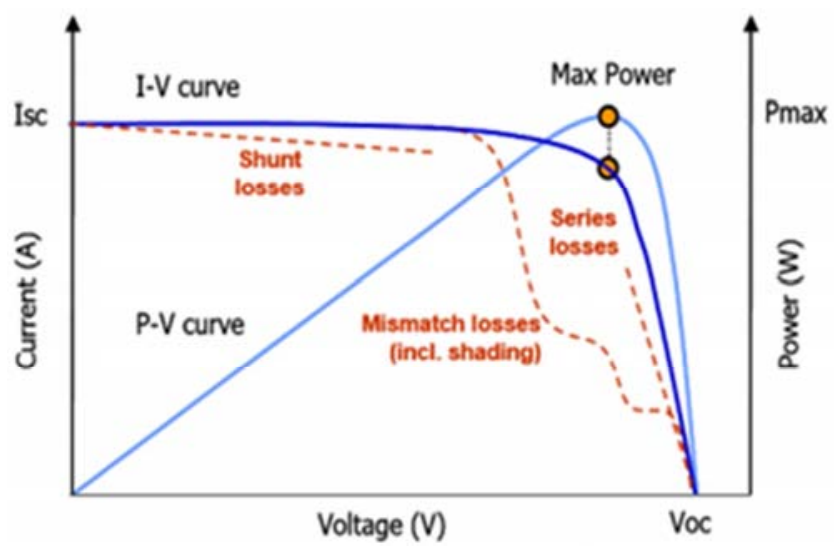

Figure 9. Several categories of losses can reduce PV array output [24].

To utilize solar energy for practical devices which need specific voltage or current for their activity, various cells must be associated together to make a panel/module.

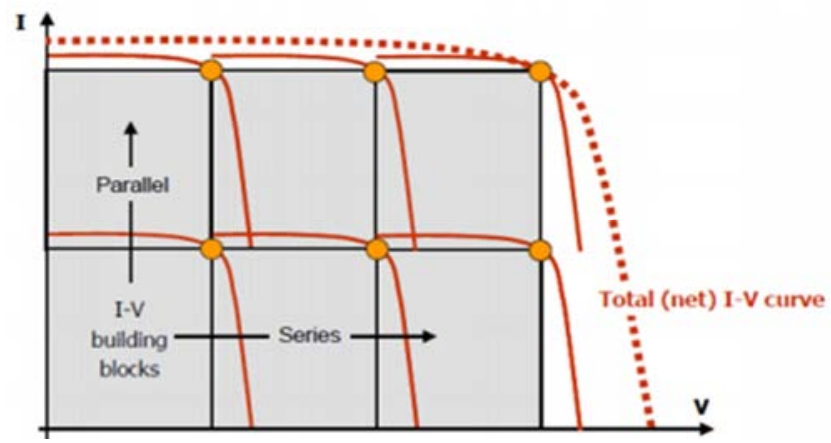

Figure 10. Scaling the current-voltage (I-V) curve from a PV cell to a PV array [24].

Photovoltaic panels are the system's core elements and are generally called power generators. For a large PV system, panels are connected in series and/or parallel to form an array. So, the maximum power point of an array can be found in 
terms of building blocks which can be represented by cell, module, or a string [26, 27]. As shown in Figure 10, each building block has a maximum power point in its upper-right corner. In case these blocks are structured together, their upper right corner represents the max power point of the array.

Efficiency is the ratio of the electrical power output (Pout), compared to the solar power input (Pin) into the PV cell. Output power can be taken to be maximum power (Pmax) since the solar cell can be operated up to its maximum power output to get the maximum efficiency $\left(\eta_{\max }\right.$.

$$
\eta=\frac{P_{\text {out }}}{P_{\text {in }}} \rightarrow \eta_{\max }=\frac{P_{\max }}{P_{\text {in }}}
$$

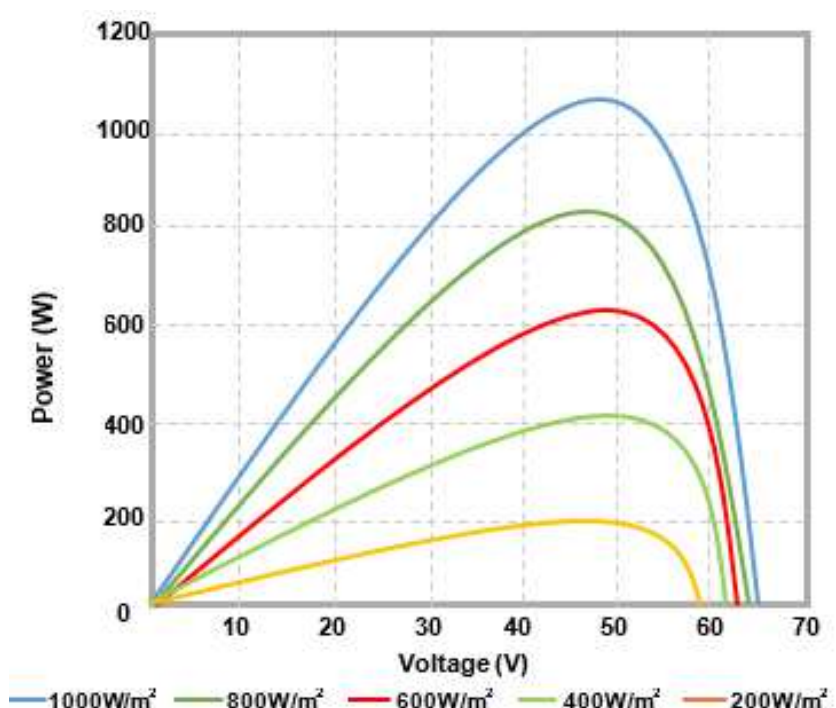

(A)

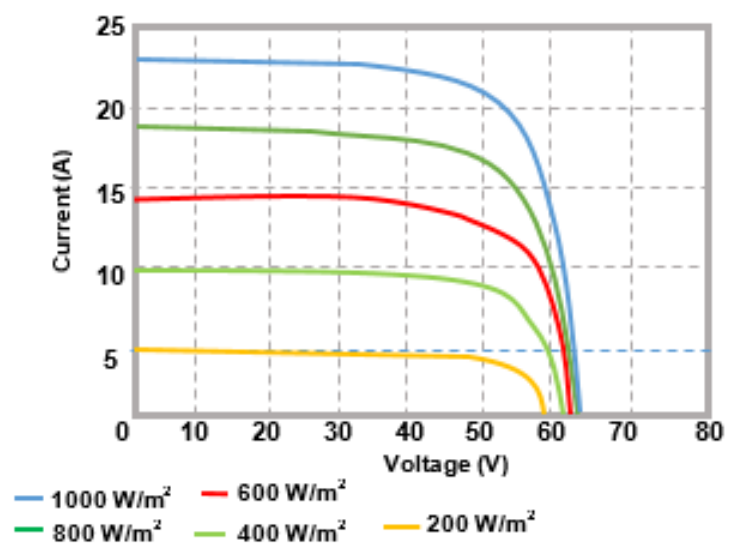

(B)

Figure 11. Effect of irradiance on PV module.

\subsection{Performance Factors of the PV System}

Many factors play a big role during energy production based on solar photovoltaic. Apart from the types and structures of solar panels which vary the capabilities of the panel, there are other external parameters which considered as major factors on PV performance. Some of those are insolation/sun's irradiance, temperature, shading, inclination, soiling, and orientation but insolation has the most impact among other factors [28]. Figure 11 shows an effect of irradiance on PV module

\subsection{Shading on PV Solar Cells}

\subsubsection{Shading Classification}

Practically some shading is inevitable in PV systems due to environmental conditions whether others can be evitable in practical conditions by varying some parameters. When shading occurs on a PV system, it can partially or completely cover a single or multiple of a cell, module, array, and string. Some can vary and others cannot vary according to their cause. Among categories, there are two main groups of shading named objective and subjective shadings. Subjective type is classified into dynamic and static shadings. Objective shadings are those which caused by weather condition like heavy cloud and haze, this kind of shading in unavoidable to the system. On the other hand, subjective shading is the one caused by shading objects according to the sun's angle like nearby buildings and trees in case of dynamic shading whereas in static type, proximity obstructions like bird droppings or other objects that can cause dirt on the module's surface. Subjective shading can be avoided by periodic cleaning, better design, and installment [29].

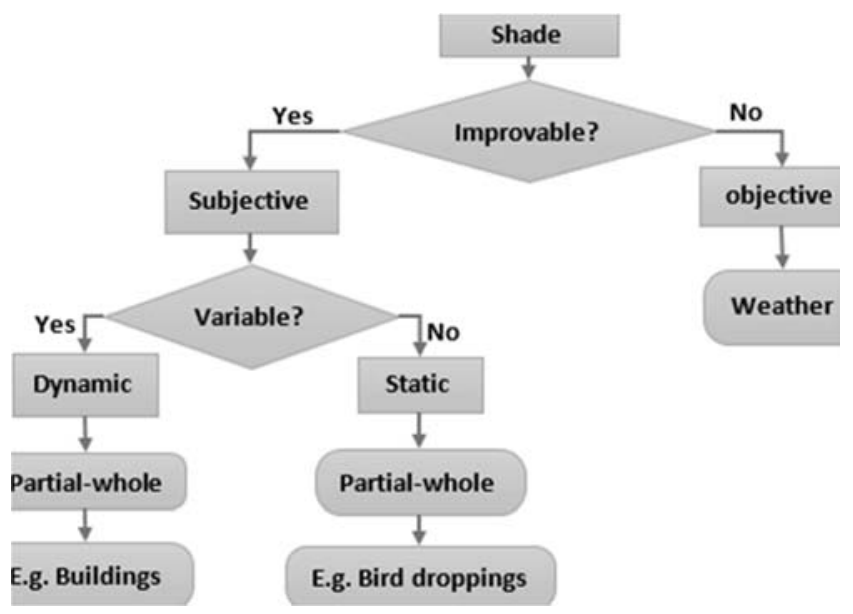

Figure 12. Shading classification [29].

\subsubsection{Mismatch Losses}

Even if PV has seen as renewable energy which has many advantages, it still has some disadvantages where one of them is a mismatch loss that can occur during energy production. The actual output is not equal to the expected one due to different causes include defects due to manufacturing, PV cell aging or other degradation, cell temperature, shading, and others $[26,30]$. So, the difference between the two values (the expected and actual power outputs) is known as mismatch losses. They can come from external or internal factors and they can be temporary or permanent sources. Like modules configuration, environmental stresses, shading is also a main of the external sources of mismatch whereas internal causes are related to manufacturing and sometimes are due to aging $[31,32]$.

\subsubsection{Effect of Shading on PV System}

The output power of an SPV system strongly depends on the 
irradiation received by a solar panel and one of the factors that can lessen the intensity of solar irradiation is a shade that can occur on the panel's surface. Environmental conditions, location, and structure of the system have taken as the main agents that cause the variation of solar irradiation [26]. For any PV system composed of a series and parallel connected modules, some modules will be affected during energy production in case shading occurs and the rate at which it was affected will depend on many factors like shaded area, modules interconnections, and rate of that shade on the cell. This degree will be determined by how much radiation is obstructed by shadow [10]. Some studies assumed that for a single cell, the effect of shading on the output power is proportionally related to the shaded area and the decrease of irradiation, submodule's layout, and the bypass diodes is an added factor on the level of array [33]. Another aspect is that shadow can be caused by a nearby module, the more the module is too closer to another the more it can cause additional power losses in cases of shading [9]. During the normal condition, the $\mathrm{P}-\mathrm{V}$ characteristics exhibit one peak as shown in Figure 13 of photovoltaic cell characteristics where that peak corresponds to the maximum power that a PV string can produce. Contrary when partial shading occurs, more than one peaks are produced include the local peaks and global peak that indicates the strings maximum power capacity. Some maximum power point trackers are not enough sensible to distinguish the global to local peaks [27].

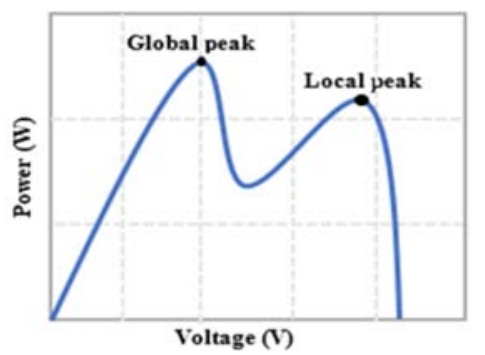

Figure 13. P-V characteristics under partial shading [27].

Practically lost power due to shading is high compared to the array shaded surface. For an array of few parallel connections, a small shaded area can cause the system output to drop to a fraction of rated power which leads to the failure of the system. When a shade occurs, the series shaded module will not be able to produce the normal output power due to the inability of voltage production and this will lead to power dissipation due to generated heat. In this case, the normal modules (unshaded modules) will need to compensate for the voltage losses entire the system, then make less current and more power losses. Those shaded modules will be no longer generators but they behave as load. Partial shading and module mismatch are also responsible for the creation of hot spots in cells of a module which reduce not only energy production but also the lifespan of the module $[10,34,35]$.

\section{Research Methodology}

This method is composed of two-part, one for experimentation in the University of Rwanda/ African Center of Excellence in Energy Studies for Sustainable Development (UR/ACE-ESD) High E-Tech Smart Grid Laboratory and other of PVsyst simulation. Assembly of various equipment including solar panel emulator $(1.5 \mathrm{~kW})$, mains power supply, the three-phase power quality meter, and the 3-phase industrial photovoltaic converter was used to conduct experiment named Maximum tracking with and without shading. The said devices are linked in some cases via different interfaces (Ethernet or USB) to the PC. The simulation for this study was done by use of PVsyst software (PVsyst 7.0.6 version). It is incorporated with a three-dimension computer-aided design (3D CAD) displaying climate and deals with the impacts brought about by the obstructions due to the environment [36, 37]. However, the purpose of this study is not a design, there are requirements to be defined in the software which include Geographical data, Meteorological data (imported from Meteonorm), Technical data (tilt and azimuth), 3D model scene for near shadings, PV modules configuration based on accessible rooftop region, and PV framework segments looked over the PVsyst database include a module, inverter, and strings. Based on the above parameters in the program for a chosen system size, the different system simulations were performed and compared for better understanding. In this work, a studied system was simulated within PVsyst software (7.0.6 version) under two conditions, one without shading and the others with it. In this study, the general working principle of PVsyst is explained where different steps to follow have been shown in detail.

\subsection{System Analysis}

Table 2. Electrical Characteristics.

\begin{tabular}{ll}
\hline Parameters & Specifications \\
\hline Nominal Power [Wp] & $50 \mathrm{~W}$ \\
Short circuit current [Isc] & $2.930 \mathrm{~A}$ \\
Open Circuit Voltage [Voc] & $22.10 \mathrm{~V}$ \\
Maximum Power Current [Imp] & $2.760 \mathrm{~A}$ \\
Maximum Power Voltage [Vmp] & $22.10 \mathrm{~V}$ \\
Number of Cells in series & 36 \\
Number of cells in parallel & 1 \\
Number of the bypass diode & 2 \\
Efficiency & 34.69 \\
\hline
\end{tabular}

Table 3. Mechanical Characteristics.

\begin{tabular}{ll}
\hline Parameters & Specifications \\
\hline Types & Monocrystalline silicon \\
Frame & Aluminum \\
Length & $540 \mathrm{~mm}$ \\
Width & $670 \mathrm{~mm}$ \\
Thickness & $30.00 \mathrm{~mm}$ \\
Module area & $0.144 \mathrm{~m} 2$ \\
Weight & $4.20 \mathrm{~kg}$ \\
Connections & JBox \\
\hline
\end{tabular}

Characteristics of the used module: In the simulation, a $50 \mathrm{Wp}$ monocrystalline module with 36 cells of generic type has been used. Tables 2 and 3 show the important parameters of the above-stated module with its specifications in STC conditions, means at $\left(1000 \mathrm{~W} / \mathrm{m}^{2} .25^{\circ} \mathrm{C}\right)$. 
For a better understanding of the basics of PV module/array characteristics, the IV characteristics which are generally found from manufacturing data sheets have been viewed. According to various manufactures, the PV characteristics are different due to used solar cell as well as their qualities. An IV and $\mathrm{P}-\mathrm{V}$ relations of a single cell are expanded from a PV module as well as to an array. Figure 14 shows the I-V and P-V curves of the selected module based on incident irradiance. There are various models for any operation of the typical solar cell where the five main parameters are considered as they use for the above-stated relations for a single solar cell [8].

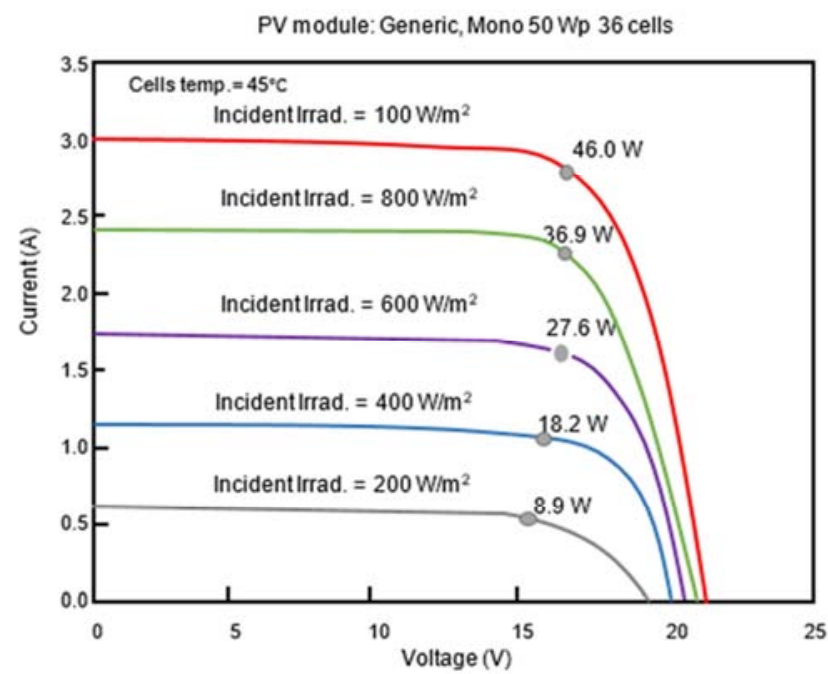

(A)

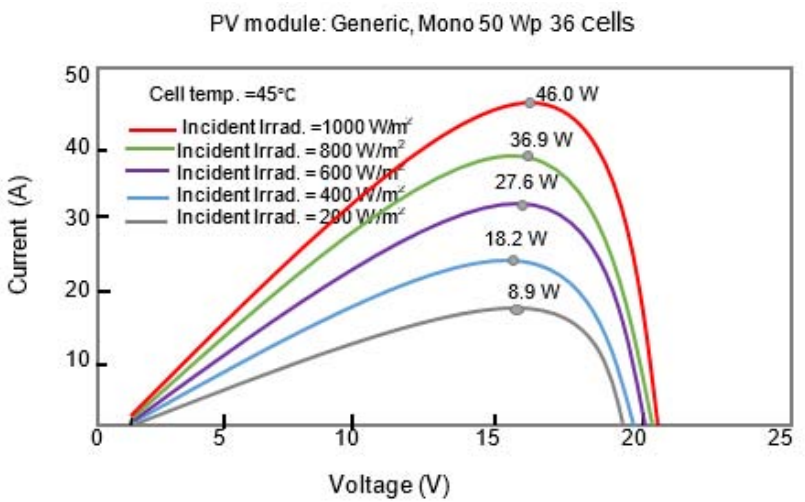

(B)

Figure 14. I-V and P-V curves of the selected module are based on incident irradiance.

\subsection{Analysis of Electrical Behavior of Shaded Modules}

Before going to the simulation, it is better to see how PV modules behave during shading conditions in different configurations. This was done within the PVsyst toolbox.

The shaded cell is no longer a power producer but absorbs power produced by other unshaded cells and its temperature increases. In Figure 16, its power has reduced and the temperature raised to $321^{\circ} \mathrm{C}$. This mostly leads to cell destruction due to preventive powers within the cell. When the cell/module is connected in an array, the array's MPP may push a much current than the one at the normal module's short circuit point. The fact is that when a cell is shaded, its current raises and exceeds its rated Isc (short circuit current) and then no longer be forward biased, so absorbed power becomes very large (results in the hot spot creation). To limit the shaded cell's power consumption, a bypass diode (anti-parallel) is added to each submodule [38].

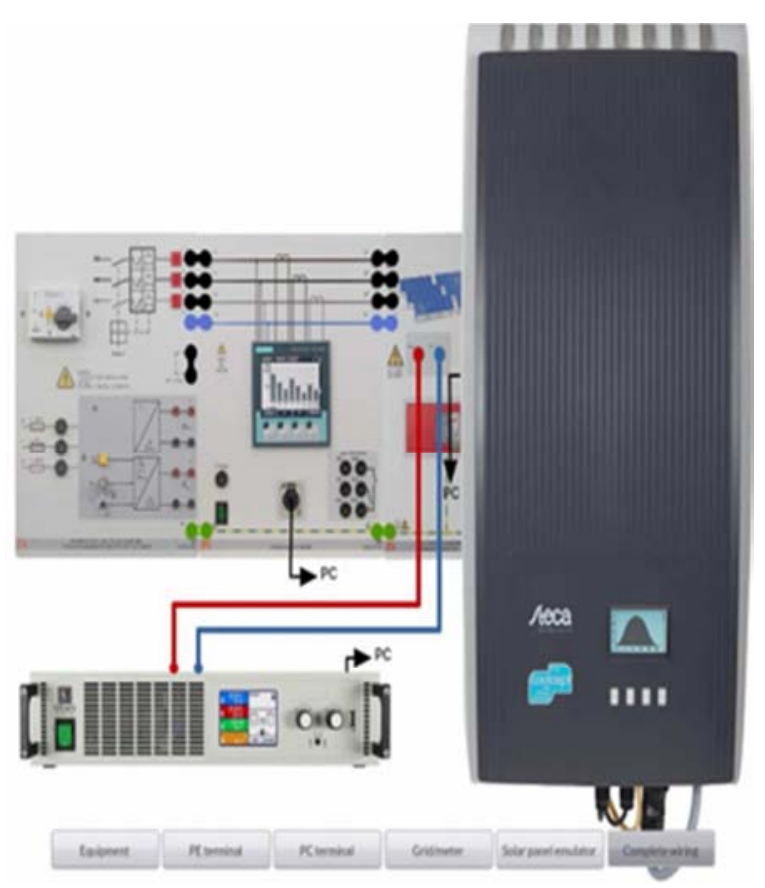

Figure 15. Experimental set up

\subsection{Laboratory Experiment}

According to the nature of the experiment and laboratory structure, the set of the equipment stated in Table 2 was used to see how shadow affects the characteristics of PV systems where the following conditions were studied and the same processes were followed in each case:

Case 1: when irradiance is $100 \%\left(1000 \mathrm{~W} / \mathrm{m}^{2}\right)$, number of shaded modules $=0$ and shadow of $0 \%$ )

Case 2: when irradiance is $100 \%$, number of shaded modules $=2$ and shadow ratio $=20 \%$

Case 3: when irradiance is $100 \%$, number of shaded modules $=5$ and shadow ratio of $50 \%$

Case 4: when irradiance is $100 \%$, the number of shaded modules $=5$ at a shadow ratio of $100 \%$.

\subsection{PVsyst Simulation}

In this study, a simulation is implemented by using PVsyst software to found the effects of shadow for a selected system. For this software, location means a study area and geographical is about coordinates. The studied system was assumed to be located in Rwanda, a Migera cell in Kayonza District. The place's geographical coordinates are so important to start the study. With the help of geographical coordinates, the meteorological data of the selected place was imported into the program database. 


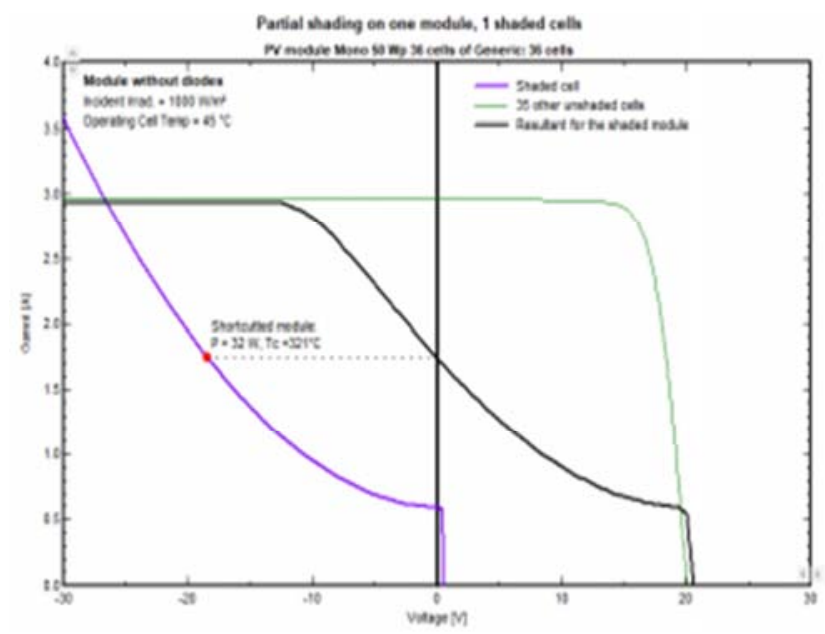

Figure 16. PV module with one shaded cell, without protection

Based on Meteonorm 7.3, the location's solar insolation is $4.98 \mathrm{kWh} / \mathrm{m}^{2} /$ day, wind speed is $2.8 \mathrm{~m} / \mathrm{s}$, annual temperature on the average basis is $20.8^{\circ} \mathrm{C}$ and relative humidity of $68.8 \%$ per year at the latitude of $-1.91^{\circ} \mathrm{S}$, longitude $30.60^{\circ} \mathrm{E}$ or $-1^{\circ} 54^{\prime} 37^{\prime \prime} \mathrm{S}$ and $30^{\circ} 35^{\prime} 56^{\prime \prime} \mathrm{E}$ and altitude of $1378 \mathrm{~m}$ above sea level (Figure 17). Because minimum meteorological data for the place is required for simulation, here the program allows user to choose which data can be calculated where at least two of them is required. Those data include:

Global horizontal irradiation

Horizontal diffuse irradiation

Horizontal beam

Normal beam

Relative humidity

Wind Velocity

Ambient Temperature

Global tilted plane

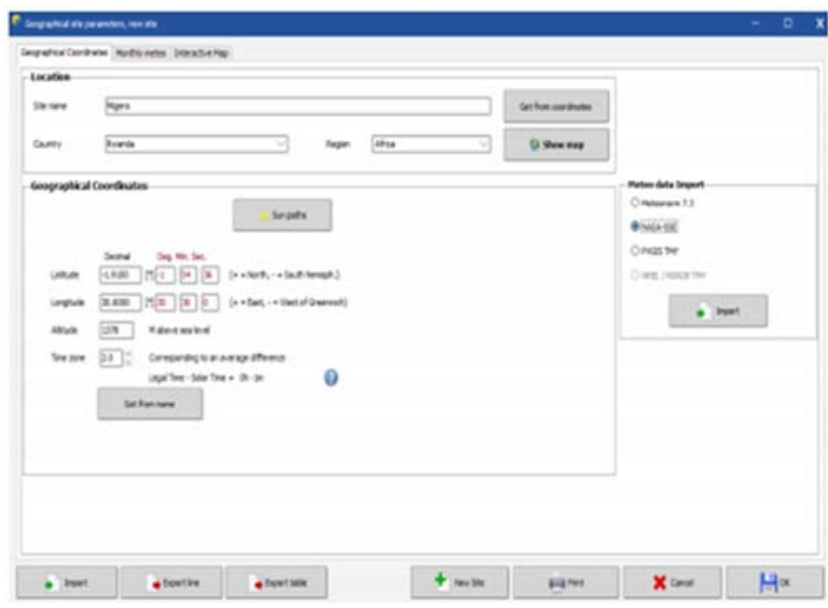

Figure 17. Site location and geographical coordinates. Table 4. Monthly values of Meteo data [Source: PVsyst]

\begin{tabular}{|c|c|c|c|c|c|c|}
\hline & $\begin{array}{l}\text { Global horizontal } \\
\text { irradiation }\end{array}$ & $\begin{array}{l}\text { Horizontal diffuse } \\
\text { irradiation }\end{array}$ & Temperature & Wind velocity & Linke turbidity & $\begin{array}{l}\text { Relative } \\
\text { humidity }\end{array}$ \\
\hline & $\mathrm{kWh} / \mathrm{m}^{2} / \mathrm{day}$ & $\mathrm{kWh} / \mathrm{m}^{2} / \mathrm{day}$ & ${ }^{\circ} \mathrm{C}$ & $\mathbf{m} / \mathbf{s}$ & {$[-]$} & $\%$ \\
\hline January & 4.92 & 2.38 & 21.5 & 3.2 & 4.105 & 64.6 \\
\hline February & 4.85 & 2.72 & 22.4 & 3.41 & 4.22 & 57.1 \\
\hline March & 5.02 & 2.42 & 22.3 & 3.29 & 3.762 & 63.6 \\
\hline April & 4.9 & 2.49 & 21 & 2.59 & 3.147 & 74.4 \\
\hline May & 5.09 & 2.35 & 20.7 & 2.39 & 3.205 & 74.8 \\
\hline June & 5.19 & 2 & 19.6 & 2.4 & 3.62 & 72.9 \\
\hline July & 5.31 & 2.01 & 19 & 2.4 & 4.01 & 72.8 \\
\hline August & 5.15 & 2.13 & 19.7 & 2.5 & 3.957 & 70.7 \\
\hline September & 4.99 & 2.37 & 20.3 & 2.7 & 3.523 & 67.7 \\
\hline October & 4.97 & 2.63 & 21.4 & 2.9 & 3.34 & 66.1 \\
\hline November & 4.66 & 2.5 & 20.7 & 2.89 & 3.206 & 73.3 \\
\hline December & 4.74 & 2.13 & 21.4 & 3.19 & 3.577 & 67.6 \\
\hline Year & 498 & 2.34 & 20.8 & 2.8 & 3.64 & 68.8 \\
\hline
\end{tabular}

\subsection{Process Description}

After seeing how the program considers the effect of shaded cells in system configuration, the next step is to see the effect of shading in the yearly system output.

The processes followed in the simulation have been shown step by step until the production of IV and PV curves. To perform the study accurately, firstly the project design option has been chosen among other options and the study was performed as a grid-connected. This option contains necessary features desired for the study with the aim of project analysis.

The second step allows the user to name the project and after that, the file of the metrological data for the selected location is imported from the database of the program. Also, the named project can be saved to the program's working place.

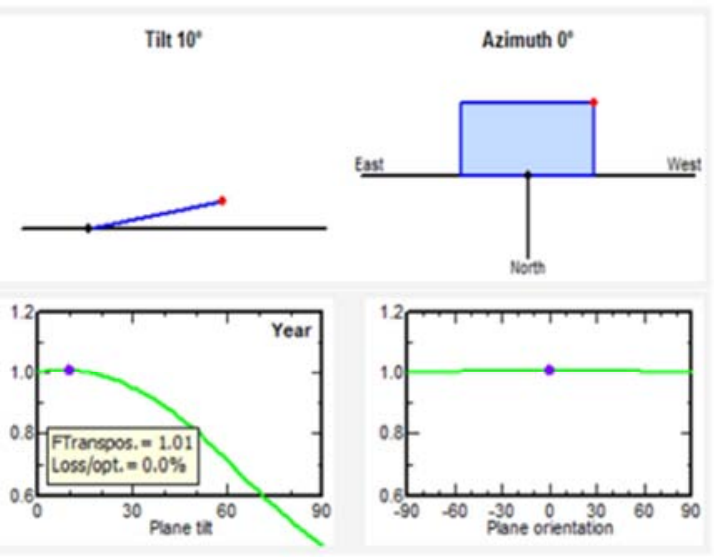

Figure 18. Tilting and orientation of the photovoltaic module. 


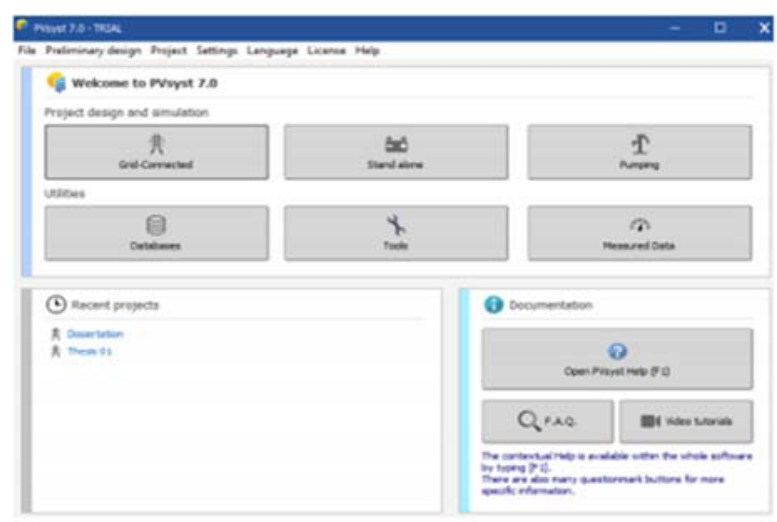

Figure 19. Program's main contents.

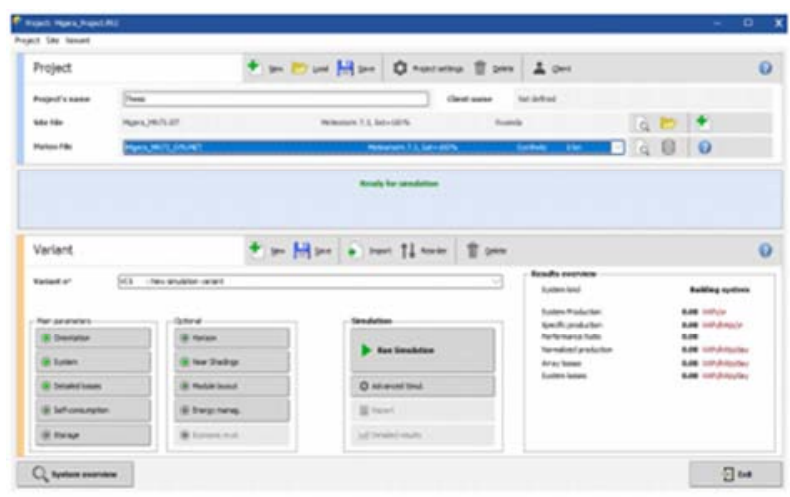

Figure 20. Project's identification.

After the identification of the project and importing the required metrological data for the selected location, the next step is to define how the system will be oriented. Here the system is a fixed tilted plane, inclined at $10^{\circ}$ to south. Those angles were taken by considering the maximum yearly Meteo yield. This step is necessary to determine the amount of daylight that strikes the surface of the panels. Always, the panel is oriented according to the sun's direction. According to Figure 18, it is possible that both tilt and azimuth angles can be varied for maximum energy production by considering those three factors like transportation factor, a loss which corresponds to optimum, and the global incident on collector plane.

And with those angles, various solar irradiation on the system's panels can be easily observed. Figure 21 shows the sun path and horizon profile for a selected place (Migera). It represents the sun's height concerning the azimuth angle and it shows a statistical relation between the azimuth angle and the sun's height at a specific time (hours) of the day.

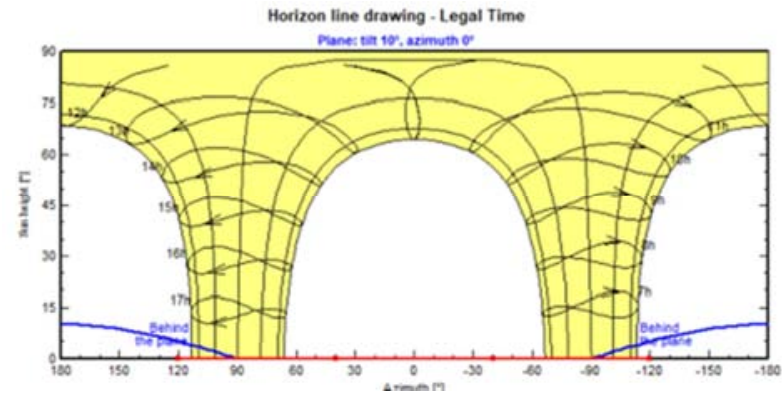

Figure 21. Sun path and horizon profile for Migera.
The above figure shows the sun's movement and is related to the values of tilt and azimuth angles in solar insolation falling on the module. The system characteristics in PVsyst allow you to size your system according to available technologies and corresponding manufacturer's specifications. Point-by-point data of wanted power at the output, inverter, and module to be used based on the manufacturer and available size; technology and output power (Wp), the effect of shading, etc. are needed to input the system. It is in this section where you define the number of modules and string of the system. Here you can also determine what number of modules will be parallel or series-connected. In this simulation, a monocrystalline $50 \mathrm{Wp}$ generic module and a $1.5 \mathrm{~kW}$ inverter were chosen. The system is made of 2 strings of 15 modules per each (Figure 22). Based on the operating conditions of the selected components (modules and inverter), the program allows the user to select the system which doesn't violate the electrical properties of the components (it should be adequately sized, not oversized or undersized).

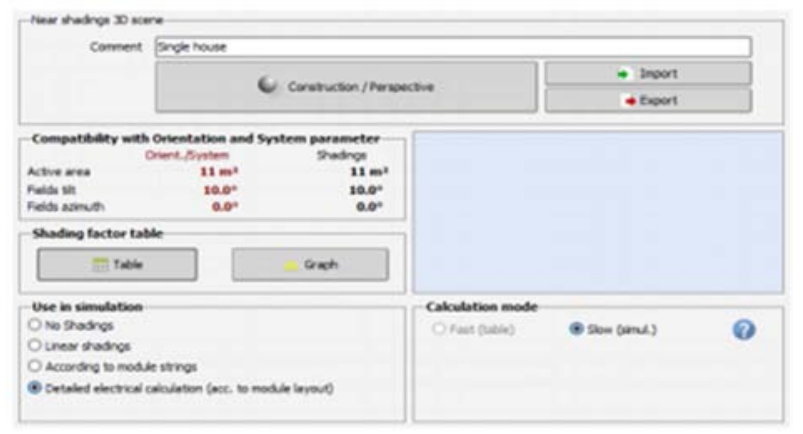

Figure 22. Near shading definition.

In the next step, a shading scene is required so that it can be applied to evaluate its effect on the system. Here the scene is constructed in a three-dimensional plane enclosed in the program. The proposed scene for this study is shown in the 3D tool (Figure 23). After the near shading construction scene, it is better to see how shading effects will be calculated. In this work, calculation according to the module layout has been chosen as it considers all detailed electrical losses calculations. Below are drawings in PVsyst 3D for the studied system (Figures 24 and 25).

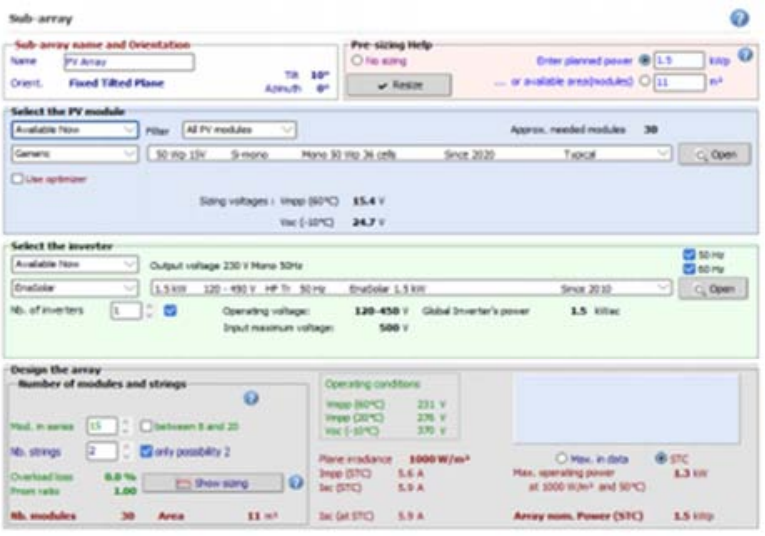

Figure 23. System definition. 


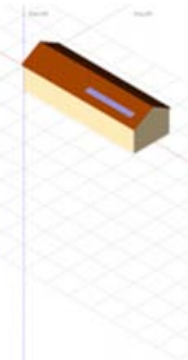

Figure 24. The system without near shading in $3 D$.

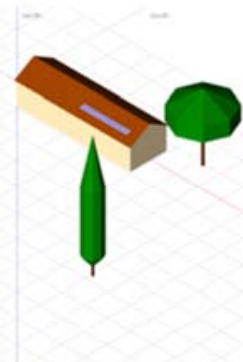

Figure 25. The system with near shading (surrounding) in $3 D$.

In this study, various shading conditions were simulated to see their respective P-V and I-V curves. During this process, various near-shading objects were applied to the system and it has shown that their effects can vary differently at a specific time of the day. To see their effects, a roof with $10^{\circ}$ tilt without shadow and a roof with $10^{\circ}$ tilt with shadow in different situations were used for the study. Another important simulation step for this study is module layout where the system is detail simulated for a chosen day of a year. The main parts for this step (module layout) are mechanical, electrical, shading 3D, and IV \& PV curves.

Mechanical: Here is a mechanical arrangement of modules on elementary sub-field areas as defined in the 3D scene.

Electrical: Here each module of the system should be attributed to an electrical string defined in the second step of the simulation processes (system definition).

Shading 3D: After attribution of each module in the system, the next step is to choose a date of a year where you want to evaluate shading effects on the system.

IV \& PV curves: After electrical shading calculations, here the results are displayed (Figure 26).

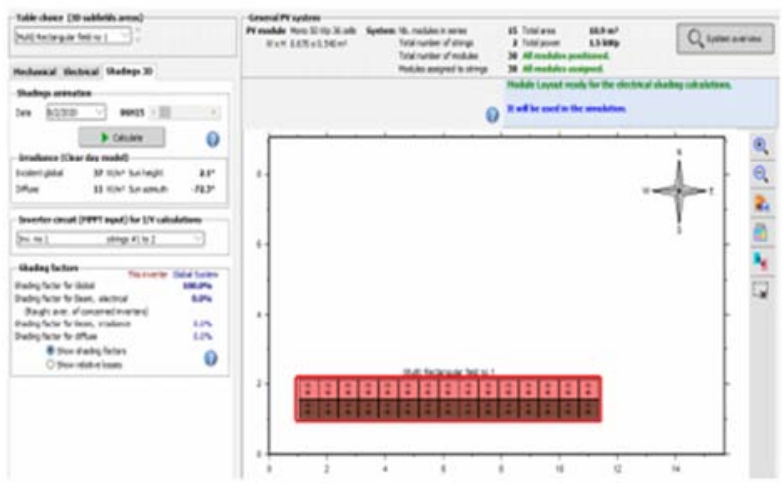

Figure 26. Definition of the module layout.
During 3D shading calculation, there is the identification of by the program of how each module/submodules are shaded where it expresses their states in terms of corners. One shaded corner of Submodule represents $25 \%$ shaded, two shaded corners represent $50 \%$ shaded, three shaded corners represent $75 \%$ shaded and four shaded corners represent $100 \%$ shaded. Each module in the system is composed of 2 submodules and a whole array is formed by 36 modules has a total number of 60 submodules. During the simulation, various shading objects have been applied to the system to vary the shading conditions, and below are performed conditions to see how shade affects the system. Figures 27 and 28 represent two simulated conditions. Condition 1 is when the array was not shaded and condition 2 is when the array is shaded. In condition 2, the grey triangle indicates the shadow.

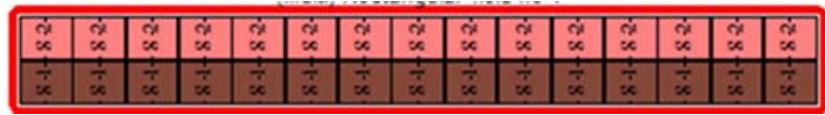

Figure 27. Condition 1: No shade on the system.

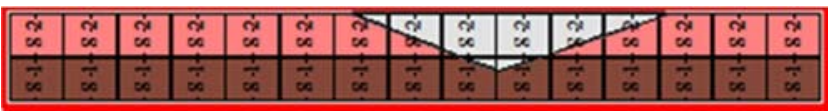

Figure 28. Condition 2: Shaded system.

\section{Results and Discussion}

Within this part, study results are shown as well as discussed following the study's aim which was to analyze the shading effects in PV systems. The simulation and validation of both non-shaded and shaded PV systems have been done and then their comparison is based on performances.

\subsection{Experimental Results}

Figure 29 shows the $\mathrm{I}-\mathrm{V}$ and $\mathrm{P}-\mathrm{V}$ curve for condition 1 when irradiance is $100 \%\left(1000 \mathrm{~W} / \mathrm{m}^{2}\right)$, number of shaded modules $=0$ and shadow of $0 \%$. The measured quantities on DC side were Power $(\mathrm{Pdc})=1440 \mathrm{~W}, \mathrm{I}=3.95 \mathrm{~A}$, and $\mathrm{V}=364$ Volts. Figure 30 shows I-V and P-V curves for condition 2 when irradiance is $100 \%$, number of shaded modules $=2$ and shadow ratio $=20 \%$. The measured quantities on DC side were Power $(\mathrm{Pdc})=1301 \mathrm{~W}, \mathrm{I}=3.48 \mathrm{~A}$, and $\mathrm{V}=374$ Volts.

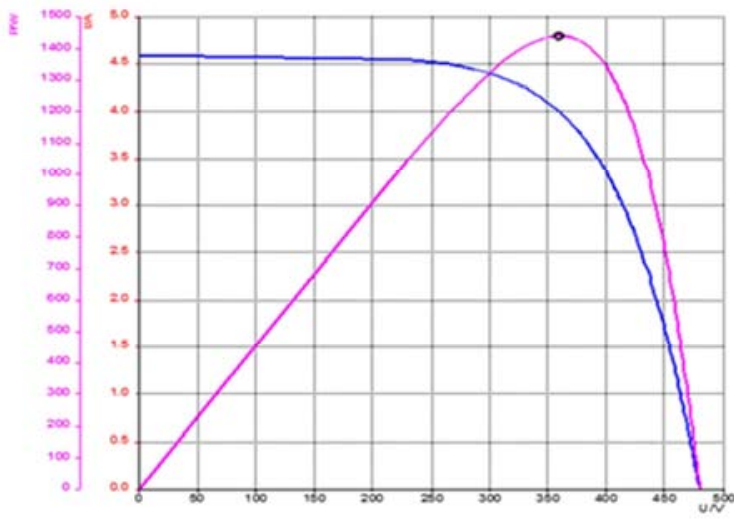

Figure 29. 100\% of irradiance and no shadow. 


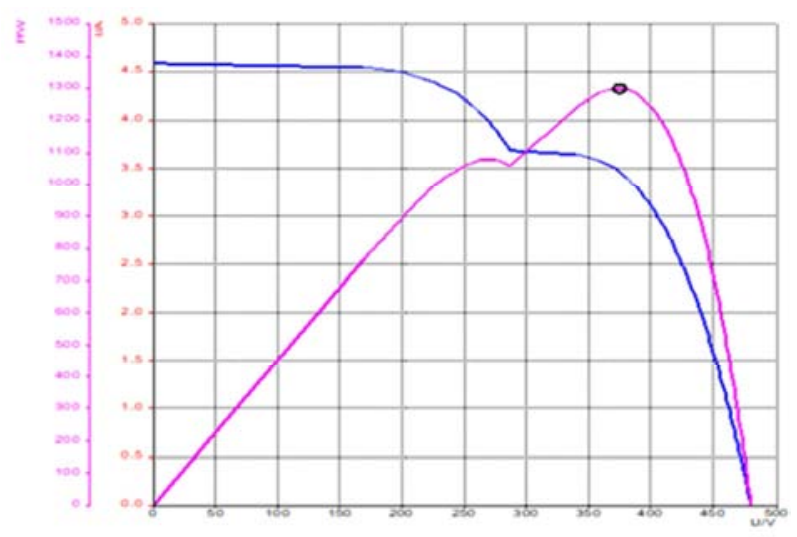

Figure $30.100 \%$ of irradiance at $20 \%$ of shading ratio.

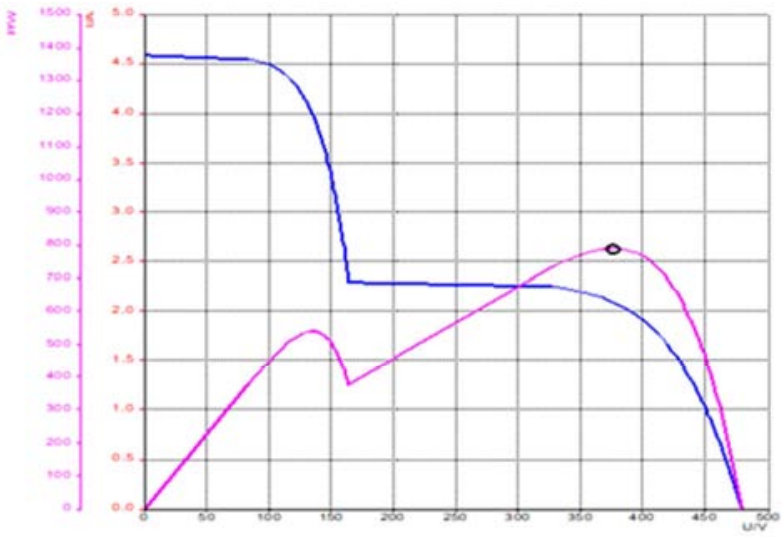

Figure 31. Shaded modules $=5$ at $50 \%$ of shading.

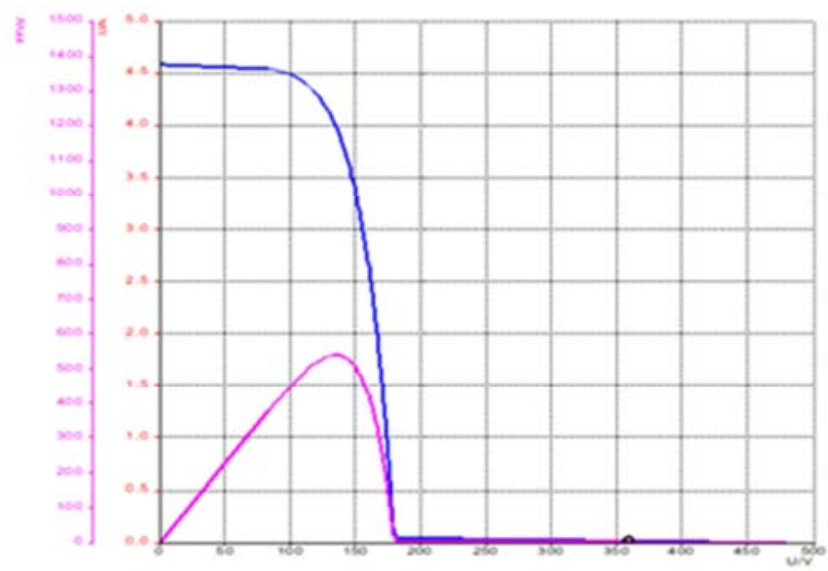

Figure 32. Shaded modules $=5$ at $100 \%$ of shading.

Figure 31 shows the I-V and P-V curves for the condition when irradiance is $100 \%$, shaded number modules $=5$, and a shadow of $50 \%$. The measured quantities on DC side were Power $(\mathrm{Pdc})=800 \mathrm{~W}, \mathrm{I}=2.6 \mathrm{~A}$, and $\mathrm{V}=370$ Volts. Figure 32 shows the $\mathrm{I}-\mathrm{V}$ and $\mathrm{P}-\mathrm{V}$ curves for the condition when irradiance is $100 \%$, shaded number modules $=5$ at shadow ratio of $100 \%$, no measured quantities were found. From the experiment, it was observed that whatever shade is applied to the system, the DC voltage and current change (increases or decreases) while DC power decreases. However, the maximum power points were obtained. It was also noted that by an increasing number of shaded modules, DC voltage increases while the DC current and power drop accordingly. Another observation is when a maximum shading ratio $(100 \%)$ is applied to the system where the resulted characteristics are out inverter MPP voltage range, the algorithm became unable to find the MPP of the system (Figure 32).

\subsection{Simulated I-V and P-V Curves for Studied Conditions}

Because the program values hourly incident global irradiations, shading effects have been calculated according to the insolation that stroked the panels during the evaluation time. August $2^{\text {nd }}, 2020$ has been chosen for the study, generally, the irradiation varies during specific times of a day as well as the day of a year. In each situation, shading can be taken into account due to the sun's position.

Based on Figure 33, when the panels were receiving 910 $\mathrm{W} / \mathrm{m}^{2}$, insolation that has been received by panels was completely converted into expected power with no electrical and irradiance losses and one MPP has been exhibited as per $\mathrm{P}-\mathrm{V}$ characteristics.

Regarding Figure 34 when the panels were receiving 540 $\mathrm{W} / \mathrm{m}^{2}$, the panels were expected to generate $756 \mathrm{~W}$ unless $419 \mathrm{~W}$ of maximum power was generated with a mismatch of $337 \mathrm{~W}$. It has been noted that around 90W (11.9\%) has been lost due to irradiance losses resulted from shading and electrical losses which include inverter losses. It has also been noted that the system exhibits more than one maximum PowerPoint that can be complicated for some inverters to distinguish the real peak.

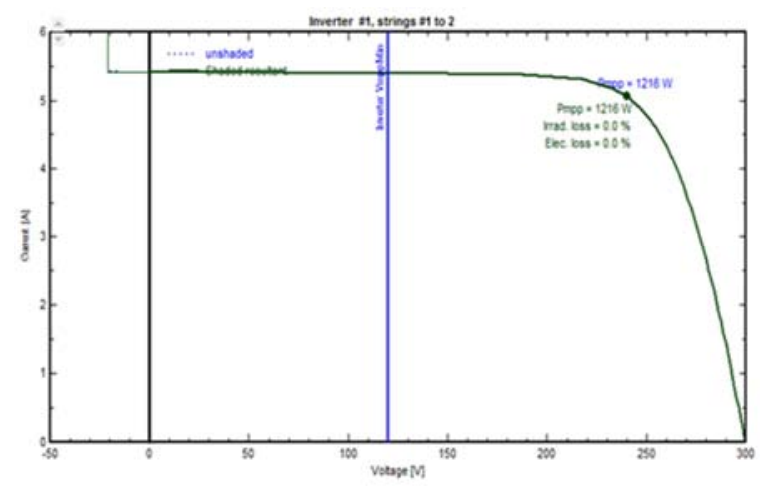

(A)

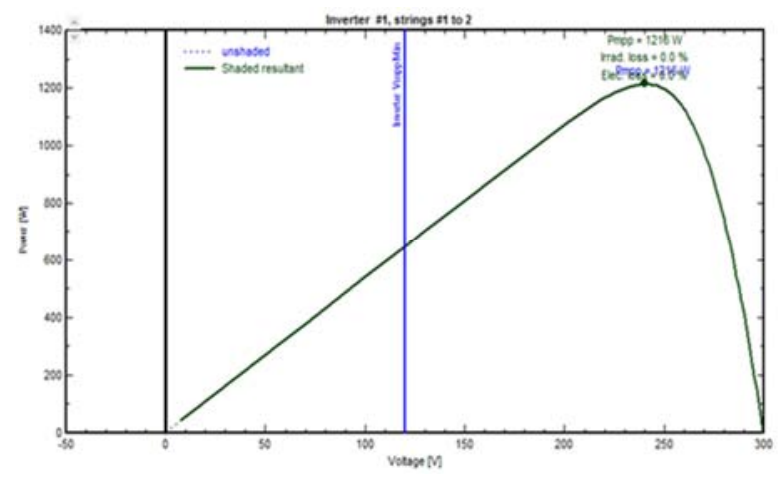

(B)

Figure 33. $I-V$ and $P-V$ curves when no shadow is considered. 


\subsection{Main Simulation Results}

The main results for detailed simulation are system production (produced energy), specific production, performance ratio, normalized production, array losses, and losses of the system. Table 5 illustrates annual energy production for studied conditions, it has been seen that energy production in the non-shading condition is $2172.8 \mathrm{kWh}$ and $2055 \mathrm{kWh}$ in the case of the shaded condition. Based on this result, the effects of shading in terms of energy are represented by $5.4 \%$ of reduced energy.

\subsubsection{Normalized Production}

Normalized production represents three different variables; losses of the system, assortment (collection) losses, and delivered valuable (useful) energy. Those factors determine the system performance in terms of energy production which are helpful in the determination of the system's performance concerning produced energy. Based on Figures 35 and 36, normalized production shaded submodule, the losses are equal to system losses $+\mathrm{PV}$ array losses $=0.24+0.78=1.02$ $\mathrm{kWh} / \mathrm{kWp} /$ day while the useful energy produced is $3.97 \mathrm{kWh}$, this represents the percentage difference between losses and useful energy of $25.6 \%$.

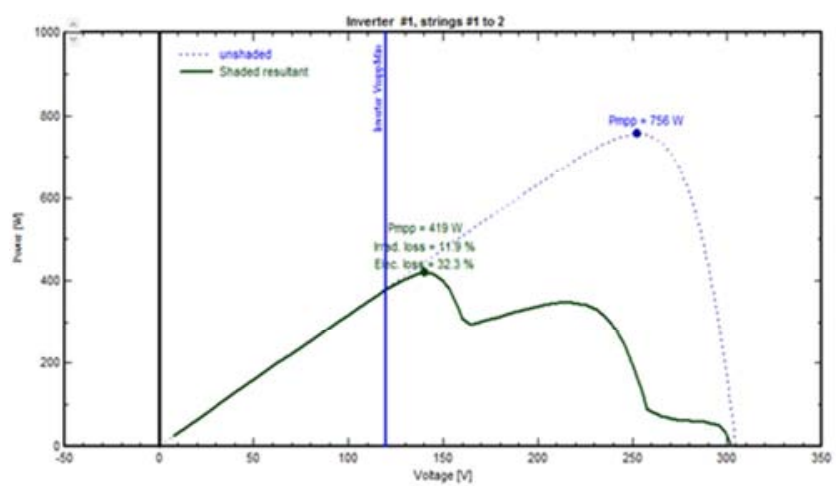

(A)

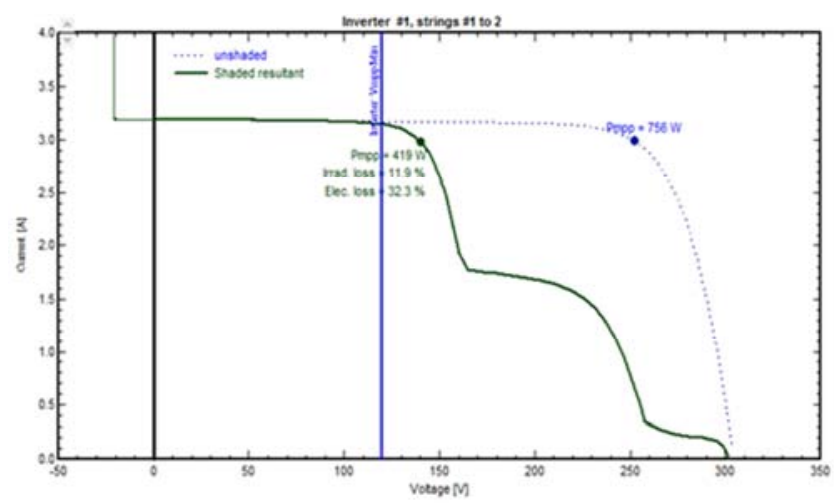

(B)

Figure 34. $P-V$ and $I-V$ curves for shading condition.

For both conditions, the highest useful energy was produced in Jun and July as it is in the sunny season. Meanwhile, normalized production in the case of shaded condition (Figure $36)$, system losses with collection losses were $1.14(0.24+$
$0.9=1.14 \mathrm{kWh})$ of useful energy produced $(3.85 \mathrm{kWh})$; and this represents the percentage difference between losses and useful energy of $29.6 \%$.

\subsubsection{Performance Ratio}

The performance ratio is taken as the efficiency of the system globally due to nominal power installed as well as the incident energy. Figures 37 and 38 show a small difference between both performance ratios of 0.795 and 0.772 (for non-shaded and shaded conditions respectively) because the system was less affected.

For a grid-connected system $\mathrm{PR}=(\mathrm{E}-\mathrm{Grid} \times \mathrm{PnomPV})$. Where E Grid is the available energy at inverter output and PnomPV is STC installed power (manufacturer's nameplate value). It includes optical losses (shading effects, soiling, IAM), array losses (wiring, mismatch, module quality, aging, photovoltaic, and among others), and system losses (inverter efficiency) [39].

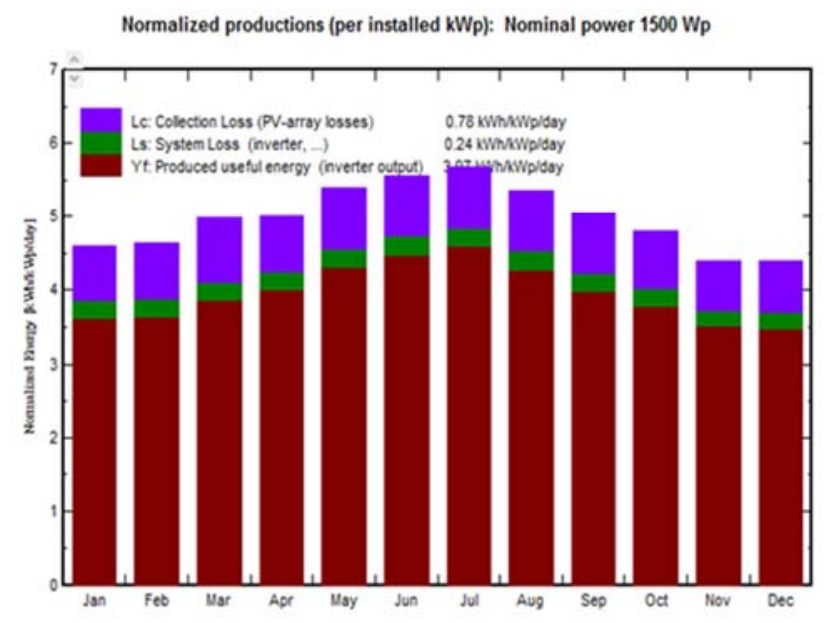

Figure 35. Normalized production for unshaded.

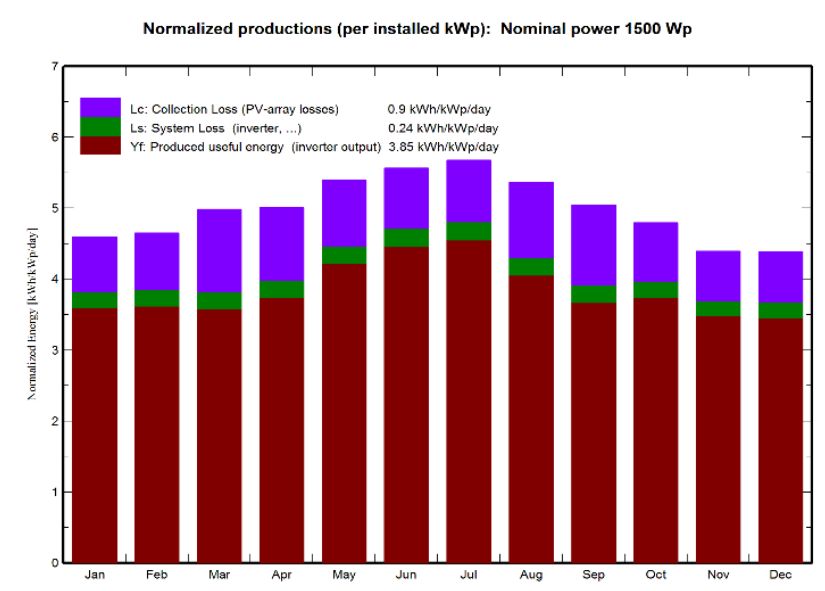

Figure 36. Normalized production for shaded. 

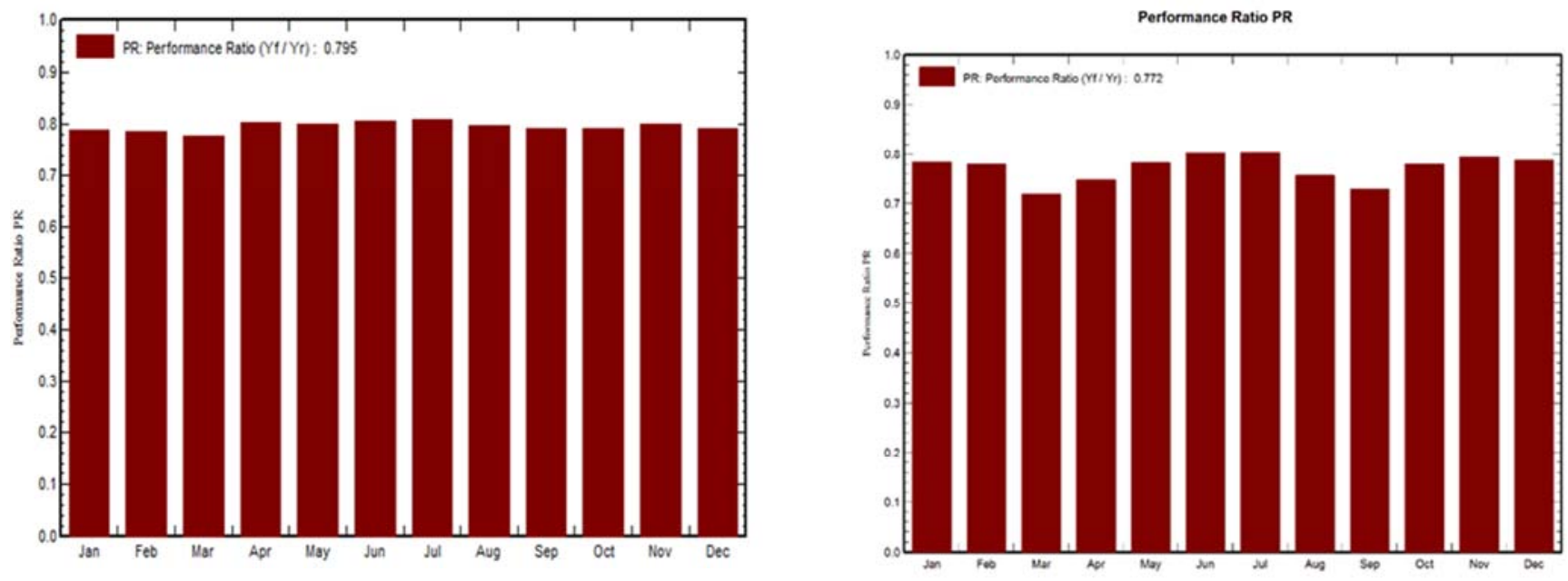

Figure 37. Performance ratio for unshaded.

Figure 38. Performance ratio for shaded.

Table 5. Annual energy produced in different cases.

\begin{tabular}{lll}
\hline Months and their respective energy production & $\begin{array}{l}\text { Produced energy by a system with shadow in } \\
\text { kWh }\end{array}$ & $\begin{array}{l}\text { Produced energy by a system without shadow } \\
\text { in } \mathbf{k W h}\end{array}$ \\
\hline January & 163.2 & 168.6 \\
February & 148.4 & 153.3 \\
March & 163.3 & 179.7 \\
April & 164.2 & 180.6 \\
May & 191.7 & 200.4 \\
June & 193.6 & 201.7 \\
July & 206.0 & 213.5 \\
August & 185.2 & 199.2 \\
September & 161.7 & 179.7 \\
October & 169.6 & 176.3 \\
November & 152.2 & 158.2 \\
December & 156.4 & 161.7 \\
Annual energy produced in $\mathrm{kWh}$ & 2055 & 2172.8 \\
Annual reduced energy in \% & 5.4 & \\
\hline
\end{tabular}

Loss diagram for "New simulation variant" - year

\begin{tabular}{|c|c|c|}
\hline 18 & $+0.1 \%$ & $\begin{array}{l}\text { Global horizontal irradiation } \\
\text { Clobal incident in coll. plane }\end{array}$ \\
\hline & $\Rightarrow .2 .16$ & Near Shadings: irradiance loss \\
\hline & Y. & IAM factor on global \\
\hline $1727 \mathrm{kWW} / \mathrm{m}^{\prime}=4 \mathrm{~m}^{\prime}$ Colls & & Effective irradiation on cells \\
\hline etteiency at STC $=34.69 \%$ & & PV conversion \\
\hline $2580 \mathrm{kWh}$ & & Array nominal energy (at STC effic.) \\
\hline & $0.7 \%$ & PV loss due to imaciance level \\
\hline & & PV loss duo to tomporature \\
\hline & $y .0 .7 \%$ & Shadings: Electrical Loss detailed modu \\
\hline & $\alpha+0.8 \%$ & Modvio quality loss \\
\hline & $7.2 .1 \%$ & Mismatch loss, modules and strings \\
\hline & $9.1,16$ & Ohmic wiving loss \\
\hline $2240 \mathrm{kWm}$ & & Array virtual energy at MPP \\
\hline & $.5 .7 \%$ & Inverter Loss during operation (emterienc), \\
\hline & $0.0 \%$ & Inverter Loss over nominat inv. power \\
\hline & $0.0 \%$ & Inverter Loss due to max. input current \\
\hline & $0.0 \%$ & Invortor Loss over nominal inv. voltage \\
\hline & $0.1 \%$ & Inverter Loss due to power threshold \\
\hline & $0.0 \%$ & Inverter Loss due to voltage threshald \\
\hline $2100 \mathrm{kWh}$ & & Available Energy at Inverter Output \\
\hline $2109 \mathrm{kWn}$ & & Energy injected into grid \\
\hline
\end{tabular}

Figure 39. Loss diagram for unshaded.
Loss diagram for "New simulation variant" - year

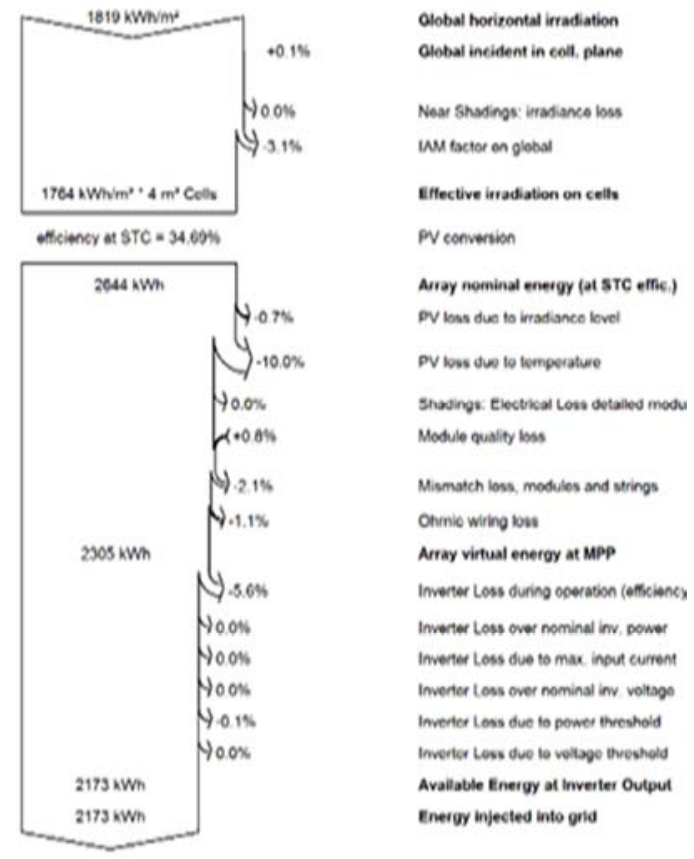

Figure 40. Loss diagram for shaded. 


\subsubsection{Detailed System Losses}

During system output calculation, the detailed losses diagram represents various losses that occur during energy production, which means from irradiance conversion to the available energy at the inverter output and injected energy to the grid (for the grid-connected system). The diagram of losses gives a clean cut into the system's quality as it identifies where those losses come from. This always presents in the simulation report for the whole year. From Figures 39 and 40, the produced energy in the yearly basics at STC is $2173 \mathrm{kWh}$ and $2109 \mathrm{kWh}$ for shaded and non-shaded systems respectively. Another special point to be noted on these graphs (Figures 39 and 40) is that there are no irradiance losses caused by near shading in the case of the non-shaded system whereas in shaded case, $2.1 \%$ of irradiation losses has been found.

\section{Conclusions}

Due to its affordability, scalability, and cleanliness, solar photovoltaic has been promised as the most dominant energy resource among other renewable energy technologies. The use of SPV systems is a solution to many countries around the world especially for low- and middle-income countries which are still struggling in providing electricity to their citizens. Leading improvement in the photovoltaic sector drove governments to raise investment in this field while researchers concentrating on numerous issues with this industry. Based on the result for this work, shadow affects the performance of PV systems and the rate at which the PV system is affected depends on the shaded area, position, and how much radiation reaches that shaded area. Shadows decrease the expected power from the shaded system as well as the system output power.

Also, the shadow changes electrical characteristics of the module/array by creating various MPP where this is contrary in the case of unshaded condition where only one peak is obtained. This increases the system's instability as it can lose its ability to generate power at the maximum due to the user control algorithm as well as degradation of the output that a PV panel can produce. PV plants installations could be installed in proper orientation of PV panels for receiving maximum solar irradiation for the efficient operation of the plant even in case of shading. It is advised to remove plantations and other things that are in the vicinity of installed modules to reduce the shadow effects on their systems. Furthermore, investigations are needed to be carried out within Rwandan Solar power plants consideration as a case study.

\section{Funding}

This research was financially supported by the World Bank and the Inter-University Council of East Africa (IUCEA) through the African Centre of Excellence in Energy for Sustainable Development (ACE-ESD) hosted at the University of Rwanda, College of Science and Technology
(CST), Rwanda. The funders, however, had no role in study design, data collection and analysis, preparation of the manuscript, and/or the decision to publish.

\section{Competing Interests}

Authors have declared that no competing interests exist.

\section{Acknowledgements}

The authors acknowledge the support from the African Centre of Excellence in Energy for Sustainable Development (ACE-ESD), University of Rwanda, College of Science and Technology (CST), Rwanda, which made this research a success.

\section{References}

[1] Ansari A. \& Rafique A. (2011) Generation of Electricity through Solar cell and Thermocouples with selling power back to Grid, 26th IEEEP Students' Seminar 2011 Pakistan Navy Engineering College National University of Sciences \& Technology, 5 .

[2] Haukkala T. (2015) Energy Research \& Social Science Does the sunshine in the High North? Vested interests as a barrier to solar energy deployment in Finland, Energy Resource and Social Science, 6 (2015), 50-58.

[3] Najafi G., Ghobadian B., Mamat R., Yusaf T., \& Azmi W. H. (2015) Solar energy in Iran: Current state and outlook," Renewable and Sustainable Energy Reviews, 9 (2015), 931942.

[4] Jäger-Waldau A. (2017) New solar power plants added almost $35 \%$ to the world-wide new power generating capacity in 2017.

[5] Masson G. \& Kaizuka I. (2017) IEA PVPS Trends 2017 In Photovoltaic Applications.

[6] Distributed Power Africa. (2020) The Future of Solar, PV an excerpts from the DPA BJCC Workshop. Available: https://dpaafrica.com/2020/01/21/the-future-of-solar-pv/.

[7] Al-Shamani A. N., Othman M. Y. H., Mat S., Ruslan M. H., Abed A. M., \& Sopian K. (2014) Design \& Sizing of Stand-alone Solar Power Systems A house Iraq, Recent Advances in Renewable Energy Sources Design, 145-150.

[8] Sala M., Alcamo G., \& Nelli L. C. (2017) Mediterranean Green Buildings \& Renewable Energy, Springer.

[9] Bimenyimana S., Norense G., Asemota O., Kemunto M. C., \& Li L. (2017) Shading Effects in Photovoltaic Modules: Simulation and Experimental Results, 2nd International Conference on Power and Renewable Energy (ICPRE), 904-909.

[10] Sun Y., Li X., Hong R., \& Shen H. (2013) Analysis on the Effect of Shading on the Characteristics of Large-scale on-grid PV System in China," Energy Power Engineering, 5, 215-218.

[11] Chaudhary A., Gupta S., Pande D., Mahfooz F., \& Varshney G. (2015) Effect of Partial Shading on Characteristics of PV panel using Simscape, 5 (10), 85-89. 
[12] Hanitsch R. E., Schulz D., \& Siegfried U. (2001) Shading Effects on Output Power of Grid Connected Photovoltaic Generator Systems," Reviews Energy Renewable: Power Engineering, 93-99.

[13] Zhou T. \& Sun W. (2014) Study on maximum power point tracking of photovoltaic array in irregular shadow, International Journal of Electrical Power Energy System, 66, $227-234$.

[14] Alam K. (2019) Techniques to Mitigate Problem of Partial Shading and Soiling on PV Module: A Review," International Journal Work, 6 (5), 148-152.

[15] Mohammedi A., Mezzai N., Rekioua D., \& Rekioua T. (2014) Impact of shadow on the performances of a domestic photovoltaic pumping system incorporating an MPPT control: A case study in Bejaia, North Algeria, Energy Conversation Management, 84, 20-29, 2014.

[16] Ekpenyong, E. E. \&Anyasi, F. I. (2013) Effect of Shading on Photovoltaic Cell, IOSR Journal of Electrical and Electronics Engineering (IOSR-JEEE), 8 (2), 1-6.

[17] Sathyanarayana P., Balla R., Lakshmi Sagar P. S., \& Kumar G (2015) Effect of Shading on the Performance of Solar PV Panel Energy and Power, 5 (1A), 1-4.

[18] Labouret A. \& Villoz M. (2010) Solar Photovoltaic Energy. The Institution of Engineering and Technology.

[19] De Lima L. C., Ferreira L. D. A., Hedler F., \& De Lima B. (2017) Development Performance analysis of a grid connected photovoltaic system in northeastern Brazil, Energy Sustainability Development, 37, 79-85.

[20] Kellenberg J. (2015) Utility-Scale Solar Photovoltaic Power Plants, Utility-Scale Solar Power Plants guidebook, International Finance Corporation, 216.

[21] Shoemaker P. (2012) Basics of Photovoltaic (PV) Systems for Grid-Tied Applications.

[22] Kim Y. S. \& Winston R. (2013) Power conversion in concentrating photovoltaic systems: central, string, and micro-inverters, John Wiley Sons, 984-992.

[23] Kumar A., Gupta N., \& Gupta V. (2017) A Comprehensive Review on Grid-Tied Solar Photovoltaic System, Journal of Green Engineering 7, 213-254.

[24] Pva A. N. (2011) Guide to Interpreting I-V Curve Measurements of PV Arrays, Solmetric.

[25] Al Bashir A., Al-dweri M., Al Ghandoor A., Hammad B., \& Al Kouz W. (202) Analysis of Effects of Solar Irradiance, Cell Temperature and Wind Speed on Photovoltaic Systems Performance, International Journal of Energy and Economic Policy, 10 (1), 353-359.

[26] Lappalainen K. \& Valkealahti S. (20170 Effects of PV array layout, electrical configuration and geographic orientation on mismatch losses caused by moving clouds, Solar Energy, 144, $548-555$.

[27] Teo J. C., Tan R. H. G., \& Tan C. (2018) Impact of Partial Shading on the P-V Characteristics and the Maximum Power of a Photovoltaic String, Energies, 11 (1860), 1-22.

[28] International Trace Software (2020) Which factors shall you consider for the installation of photovoltaic panels? Available: https://www.trace-software.com/blog/which-factors-shall-youconsider-for-the-installation-of-photovoltaic-panels/.

[29] Bulanyi P. \& Zhang R. (2014) Shading Analysis \& Improvement for Distributed Residential Grid- Connected Photovoltaics Systems, The $52^{\text {nd }}$ Annual Conference of the Australian Solar Council, 2014.

[30] Kaushika N. D. \& Rai A. K. (2007) An investigation of mismatch losses in solar photovoltaic cell networks, Energies, $32,755-759$.

[31] Fernando L., Villa L., Ho T., Crebier J., \& Raison B. (2013) A Power Electronics Equalizer Application for Partially Shaded Photovoltaic Modules," IEEE Transactions on Industrial Electronics, 60 (3), 1179-1190.

[32] Lorente D. G., Pedrazzi S., Zini G., Rosa A. D., \& Tartarini P. (1014) Mismatch losses in PV power plants, Solar Energy, $100,42-49$.

[33] Balasubramanian I. R., Ganesan S. I., \& Chilakapati N. (2014) Impact of partial shading on the output power of PV systems under partial shading conditions, Institution of Engineering and Technology Power Electron, 7 (3), 657-666.

[34] Kaushika N. D., Mishra A., \& Rai A. K. (2018) Solar Photovoltaics. New Delhi, Springer.

[35] Abu-Rub H., Malinowski., \& Al-Haddad K. (2014) Power Electronics for Renewable Energy Systems, Transportation and Industrial Applications, IEEE Press and John Wiley \& Sons Ltd.

[36] Muñoz Y., Vargas O., Pinilla G., Vásquez J., \& Nariño A. (2017) Sizing and Study of the Energy Production of a Grid-Tied Photovoltaic System Using PVsyst Software, TECCIENCIA, 12 (22), 27-32.

[37] Sharma D. K., Verma V., \& Singh A. P. (2014) Review and Analysis of Solar Photovoltaic Softwares, International Journal of Current Engineering and Technology, 4 (2), 725 731.

[38] MERMOUD A., LEJEUNE T. (2010) Partial shadings on PV arrays: by-pass diode benefits analysis, 25th European Photovoltaic Solar Energy Conference. 2010

[39] PVsyst 7. (2020) Performance Ratio, Available: https://www.pvsyst.com/help/index.html?performance_ratio.h tm. 